\title{
Graffiti murales de época histórica en el Castillo de Monsalud (Nogales, Badajoz)
}

\author{
Sophie Gilotte * \\ Antonio González Cordero ***
}

\section{RESUMEN}

Este artículo analiza un extenso conjunto de graffiti descubiertos sobre las paredes de dos aljibes, que forman parte de la estructura de una fortaleza islámica situada en la Sierra de Monsalud (Nogales, Badajoz). Este descubrimiento presenta un doble interés: la coincidencia del contexto arqueológico con un topónimo antiguo, mencionado por algunas fuentes árabes, hace posible la identificación de esta fortificación con el hisn emiral de Munt SalCit. Por otra parte, la riqueza de su repertorio iconográfico, no desprovisto de un cierto poder narrativo, permite establecer una amplia cronología, desde el fin de la Edad Media hasta hoy, apoyándose sobre paralelos que se escapan del simple ámbito regional. Por fin, este estudio nos permite valorar unas manifestaciones que en los estudios del Arte Rupestre en Extremadura, nunca se habían tenido en cuenta.

PALABRAS CLAVE: Graffiti, aljibe, armas, jinetes, cruciformes, zoomorfos, fortificación andalusí, Sierra de Monsalud, Badajoz.

\section{INTRODUCCIÓN}

Es la Sierra de Monsalud una continuación de la cadena montañosa de la Sierra de María Andrés. Situada en la margen izquierda de la Rivera de Nogales, en el borde occidental de la comarca de Tierra de Barros, se alza a lomos de empinadas laderas, para dominar desde su cima amplísimas extensiones, en las que el bos-

\section{RÉSUMÉ}

Cet article analyse un vaste ensemble de graffitis découvert sur les parois de deux citernes, éléments architectoniques d'une petite forteresse musulmane située dans la Sierra de Monsalud (Nogales, province de Badajoz). Cette découvert presente un double intérét: la cóincidence du contexte archéologique avec un toponyme anclen, mentionné dans quelques sources arabes, rend possible l'identification de cette forteresse avec I' hisn émiral de Munt salút. D'autre part, la richesse de son répertoire iconographique, non dénué d'un certain pouvoir narratif, permet d'établir une ample chronologie allant de la fin du Moyen ge jusqu'á l'époque contemporaine, en s'appuyant sur des paralléles qui dépassent le simple cadre regional. De méme, cette étude permet de valoriser des manifestations qui n'avaient jamais été prises en compte dans le contexte général des études sur l'art rupestre en Extrémadure.

MOTS CLEFS: Graffitis, citerne, armes, chevaliers, cruciformes, zoomorphes, fortification musulmane, Sierra de Monsalud, Badajoz.

que adehesado de encinas se une a las tierras del viñedo y olivar que caracterizan el centro de la provincia de Badajoz (Fig. I).

Sobre la cumbre del Cabezo Alto (657 m.s.n.m.), junto a la carretera que enlaza las poblaciones de Nogales y Salvaleóni, se emplazan las ruinas de una fortaleza en la que aún resisten el paso del tiempo dos construcciones,

\footnotetext{
* Casa de Velázquez. Madrid. * ** Arqueólogo

| Hoja del I.G.N. |:25.000, 828- | | | Barcarrota, edición de 1992. Coordenadas geográficas: 645'50" 0 y 38³3'54”'N.
} 
en cuyas paredes se han reproducido abundantes figuras que en sus esquemas formales, coinciden básicamente con otros motivos inscritos en diferentes sillares de edificios religiosos y rocas de la Península.

El descubrimiento de los grabados fue el detonante de una investigación más general de todo el entorno histórico-arqueológico que lo complementaba, pues al estudio del yacimiento en relación con el mundo islámico, se añadía el interés de los propios grabados murales, cuya documentación y hasta la fecha, nunca se había abordado en Extremadura. Es por eso que, independientemente de la importancia del análisis que merezca el conjunto, lo que se persigue también es una primera aproximación global, más allá de la mera tarea descriptiva, que abra el camino a futuros estudios que incidan más específicamente en diferentes facetas de la investigación del fenómeno graffilco, que como ya ocurre con las manifestaciones rupestres prehistóricas, incentive la realización un inventario en la región extremeña.

\section{METODOLOGÍA}

La reproducción de los grabados de los dos aljibes, ha sido efectuada por los dos firmantes de este trabajo copiando los conjuntos principalmente a partir de calcos. Para la obtención de estos con la mayor fidelidad posible, utilizamos numerosos recursos, en los que primó siempre el respeto absoluto hacia el soporte.

El trabajo de reproducción se realizó a partir de dos fórmulas. En primer lugar se obtuvo un calco directo sobre lámina plástica transparente, marcando sobre la misma con rotuladores indelebles de punta calibrada. Con un color distinto si se incluían los accidentes de la pared, tales como fracturas, cambios de coloración, etc. A continuación comenzó la labor fotográfica, para la cual se utilizaron carretes de diapositivas en color de 50 ASA, para intentar explotar con las mejores garantías las posibilidades que ofrece la manipulación de la luz natural y la artificial.

Más adelante las plantillas de los dibujos en polivinilo se redujeron con la ayuda de un pantógrafo, conservando así su escala exacta, hasta que su tamaño de adecuó al marco del papel vegetal con el que trabajamos y sobre los que se realizó el estudio definitivo con estilógrafos de tinta china.

\section{CONTEXTO HISTÓRICO}

La primera referencia a vestigios arqueológicos en la Sierra de Monsalud se deben precisamente al Marqués epónimo (MARQUÉS DE M. 1901: 13), el cual, en una confusa descripción da a entender que existen dos fortalezas separadas por el Puerto de los Maderos; a una la presenta como "citania", lo que en el lenguaje actual de la investigación histórica, debe entenderse como un castro u oppida de la II Edad del Hierro; mientras que a la otra se refiere directamente como un castillo romano. Esta última debe corresponder, por alusión a los "dos profundos subterráneos", y por la escueta, pero ilustrativa descripción de los mismos, a las ruinas que hemos localizado y que tal vez coincidan también con las de un informe -Estudio de impacto ambiental de la línea eléctrica 220KV Balboa-Campo Mayor (Badajoz)-, que documenta sin más precisión, fases de ocupación medieval en la Sierra de Monsalud 2.

Ninguna de los dos hasta el presente ha merecido la más mínima atención, sino fuera por un par de menciones a la hora de estudiar el poblamiento de la II Edad del Hierro en la Baja Extremadura, pues el sitio aparece primero en un mapa con la distribución de este tipo de asentamientos (RODRIGUEZ, 1989: 167) y más tarde en una cita posterior del $L$ Berro-

\footnotetext{
2 Estudio de Impacto ambiental de la línea eléctrica 220KV Balboa-Campo Mayor (Badajoz). Estudios de recursos culturales, AREA, Sociedad Arqueológica, c/ Reina, 15, 28004 Madrid. Se han documentado fases de ocupación medievales.
} 
cal, que llega a ubicar las ruinas, a tenor de las coordenadas que proporciona $\left(38^{\circ} 33^{\prime} 45^{\prime \prime}-6^{\circ}\right.$ 46' 50"), en el Pico de Monsalud, del que dice hay un «cerro fortificado y romanizado, en el conocido Mons Oxiferus, con ocupaciones romanas y medievales.» (BERROCAL 1993).

Aparte de esto, los pasajes o alusiones históricas que disponemos sobre este yacimiento son escasas y de ambigua interpretación: en efecto, sería muy atractivo reconocer en la actual Sierra de Monsalud, el topónimo que aparece en las fuentes medievales árabes como Munt 'alCit (del latín Mons-tis, monte, montaña), según P Guichard (e.p) puede indicar que este lugar estuviera sin ocupar a la llegada de los musulmanes. Las pocas crónicas árabes que nos hablan de Munt lalút (Ibn Hayyán s. X-Xl; Ibn alldári, s. XIII-XIV) relacionan este sitio con una fortaleza (o hisn) que sirvió varias veces de refugio durante la época del emirato al rebelde Ibn Marwán al-YillTqT ${ }^{3}$, fundador de Badajoz (P. GUICHARD: e.p). No obstante, unas precisiones dadas por lbn Hayyán sobre la ubicación de esta fortaleza, o más bien a través de los trayectos seguidos por el rebelde, y, por otro lado por el cuerpo del ejército omeya, han conducido a varios historiadores (MANZANO, 1991: 194) a poner seriamente en duda la localización de este Monsalud al sur de Badajoz, posición sostenida entre otros autores por Simonet, (1897-1903: 509) o Terrón (1991: 61), siendo mucho más probable en la zona del Tajo, quizás como lo propone $M$. Velho en el concejo de Ferreira do Zézere en Portugal. (VELHO, 1981: 270-287), aunque en esa zona no consta que figure un topónimo con tanta semejanza semántica como el de la sierra de Nogales, donde a medio camino entre Badajoz y Zafra, en la ruta natural hacia Andalucía, se alza estratégicamente el castillo objeto de nuestro estudio.

Por muchas que sean las contradicciones, o dudas que pueden existir, la mención a este yaci- miento no vuelve a aparecer después del emirato en las fuentes escritas. Sólo puede seguirse la huella de su topónimo a través de documentos más modernos como son, por ejemplo, el Libro de la Montería del s. XIV (MONTOYA: 1992: 622), que en su capitulo XXIII "de los montes de tierra de Badaioz et de Xerez Badaioz" hace referencia a la caza de jabalí en la sierra de Monsalud: "Monsalut es buen monte de puerco en todo tiempo et es la bozeria por çima de la sierra et son las armadas: la una en el lomo de sobre el arroyo, et la otra a la fuente". Aquí se limita a mencionar el topónimo de la sierra, esta vez sin ningún tipo de duda relacionado con la sierra badajocense, pero sin más precisión y sin mencionar la existencia de ningún tipo de ruinas. Este silencio con respecto al castillo podría confirmar su definitivo abandono y olvido en esta época ${ }^{4}$.

\section{DESCRIPCIÓN DEL YACIMIENTO}

Se ubica sobre dos pequeñas plataformas sub-horizontales culminantes a $656 \mathrm{~m}$ de altitud, separadas por una ligera depresión de 50 $\mathrm{m}$ de ancho sobre $10 \mathrm{~m}$ de alto, formando así dos conjuntos bien definidos a nivel espacial y funcional (hábitat, fortaleza). De hecho, la plataforma que domina el collado -vía de paso obligado para la Cañada Real- ve su carácter estratégico confirmado por la presencia de una fortaleza aunque de dimensiones modestas. De este recinto fortificado y dotado de importantes reservas de agua (los dos aljibes), se puede todavía apreciar una muralla de mampostería conservada en muy mal estado, flanqueada por siete torres macizas y que va siguiendo los contornos irregulares del terreno. La cortina desaparece durante un corto tramo en el sector NNE, cuando la interrumpen una paredes verticales de pizarra esquisto-grawaquicas, por lo cual resulta inútil toda obra defensiva. Del mismo modo, el haber instalado la muralla en la línea de ruptura de la

\footnotetext{
3 Sólo Ibn al-Ațir -s. XI I-XIII-, (FAGNAN, 1901: 205) relaciona este sitio con la historia del rebelde Mahmud, en época de 'Abd al-Raḥmān | |.

4 P. Madoz menciona Nogales sin mencionar las ruinas de Monsalud.
} 
pendiente, o si no en la pendiente, obliga en algunas zonas recurrir a soluciones arquitectónicas peculiares para asegurar la estabilidad de la construcción. Así, la única torre semicircular del ángulo NE,TI, se alza sobre un zócalo rectangular escalonado de aproximadamente de I,20 m de altura. Algunas otras partes de la muralla, especialmente en el tramo este, parecen adoptar este esquema, aunque de forma quizás menos pronunciada. Sin embargo, si el trazado de la muralla se puede seguir a intervalos, su lastimoso estado de conservación impide tener datos precisos sobre el modo constructivo, la altura o el ancho de la muralla, las dimensiones exactas de las torres, etc., haciéndose todavía más difícil a la hora de identificar y interpretar esos restos parcialmente visibles. Por ejemplo, mediante las observaciones de superficie, el tramo de muralla entre las torres T4 y T5 (el único donde se dejan ver a la vez los aparejos interior y exterior: línea de piedras sin elevación superficial), podría medir $3 \mathrm{~m}$ de ancho, salvo si se trata de los cimientos del zócalo, con lo cual se podría explicar estas dimensiones exageradas para una fortificación de este tamaño. Pero, tampoco se puede rechazar la posibilidad de una ampliación o refuerzo. El mismo tipo de problema surge con la torre T3 que no muestra una clara relación con la cortina. Del simple añadido a una segunda fase constructiva, el problema se complica de forma singular con los restos de paredes situados un metro atrás que podrían pertenecer a una primitiva fase del recinto o también se puede evocar de nuevo la torre T. I, la única que adopta una planta semicircular sobre un zócalo rectangular y que utiliza gran cantidad de argamasa de cal en su blocaje interior. Pero sería un poco apresurado reconocer una reforma, si no tenemos las evidencias claras que solamente podría ofrecer una excavación.

Todavía más somera será la evocación de la segunda plataforma, supuestamente ocupada por el poblado (sin embargo no quedan indicios superficiales de casas) vinculado a la fortaleza vecina. Está parcialmente delimitada por un recinto, del cual se aprecia muy poco, excepto dos torres en el lado $\mathrm{N}$ de medidas prácticamente idénticas: $3,30 \mathrm{~m} \times 6,15 \mathrm{~m}$ y
4,70 m × 6,60 m. De un lado, es bastante evidente que nunca fue cerrado totalmente, lo que va en el sentido de una delimitación casi simbólica de un espacio social, mientras que su aspecto defensivo o protector, materializado por las torres, indica que se trata ante todo de un hábitat de altura, quizás solamente ocupado durante periodos difíciles.

\section{I . Los Aljibes}

Los dos pequeños aljibes están situados en el interior del reducto, a algunos metros del lienzo noreste de la muralla y no arrimado a él como ocurre a menudo (BAZZANA, 1999: 373) con ejemplos en Carbonera (Valencia), Chulilla (Castellón) o Taberna (Alicante).

De planta rectangular, ligeramente irregular, están dispuestos perpendicularmente, sin comunicación. El más grande ( 1 ), es el mejor conservado y mide $2,72 \mathrm{~m}$. (2,75) por 4,30 m. (4.52) con una altura útil de muro de 2,202,30 $\mathrm{m}$. sobre un fondo colmado de cascotes, mientras que el segundo (II), mide solamente 3,40 m. $(3.37)$ por 3,01 m. $(3,04)$ con un altura de I ,60 m. del muro sobre un terraplén. Sus paredes están recubiertas por varias capas de argamasa, de las cuales, la última como es habitual se impregna de un color almagre.

Estas dos cisternas presentan sin embargo diferentes soluciones arquitectónicas nada despreciables, que podrían poner en cuestión su contemporaneidad. La cisterna II está casi totalmente excavada (el espesor del muro es de I, 40 m.) y el arranque de la bóveda corresponde más o menos al nivel del suelo mientras que la cisterna I solo esta parcialmente excavada y termina en una elevación de mampostería ligada con mortero de cal y cubierto de una bóveda de cañón con el arco ligeramente rebajado, bien conservada. Sus muros mucho más espesos que los de la II, están reforzados por tres contrafuertes rectangulares entre I m. y 1.30 de espesor En el interior la bóveda viene a apoyarse sobre un resalte (alrededor de $0,10 \mathrm{~m}$. de ancho) y las esquinas interiores están acabadas por una media caña vertical que aseguran su impermeabilidad. 
Las entradas de los dos aljibes se sitúan a media altura, pero con orientación diferente. En el aljibe I se abre en la pared oeste, a nivel del terreno que la estructura levantada pretende igualar y en el II hacia el este. El mantenimiento de la elevación y de la bóveda del primero, ha asegurado una mejor conservación de los graffiti que en la cisterna II.

\subsection{Hallazgos arqueológicos}

Por otra parte, los hallazgos arqueológicos mobiliares se reducen a materiales cerámicos, visibles especialmente en la superficie de la falda sureste y en la plataforma correspondiente a la zona del poblado. Con todas las precauciones y límites que suponen un estudio de superficie todavía en curso, se puede dar una adscripción como muy pronto los siglos IX-X que corresponderían a la primera fase emiral, y luego a los siglos XI-XII, haciéndose notable la ausencia de material de la época califal.

Queda abierto el problema de la cronología de estos restos arqueológicos. Algunos signos de reconstrucción o más bien de diferentes fases se pueden sospechar de algunas partes de la construcción, como en la esquina sur, donde lo que queda de una torre se levanta posiblemente delante de una fase inicial de la muralla; del mismo modo, el aljibe I presenta en su cara sureste signos de reconstrucción. Por lo demás, todo hace suponer que el yacimiento no fue reocupado después de la reconquista, o sino de forma tan esporádica y parcial que no parece haber modificado las estructuras.

\section{LOS GRABADOS}

Los grabados fueron realizados sobre un enlucido de cal y arena revocada con un pigmento de almagra rojiza hidrófuga, correspondiendo los ocho paneles del registro a cada una de las paredes que delimitan la cubeta de dos aljibes. La profundidad de los trazos varía entre 2 y 9 mm., según la amplitud del bisel o punta de los utensilios empleados, entre los que se reconocen claramente la huella de al menos tres objetos distintos; la de una especie de piqueta que produce cortes abruptos, el de una herramienta parecida a la azada de punta triangular, que dibuja secciones angula- das en $V$ y un puntero. La presencia de huellas de este último objeto en la esquina norte del aljibe I, nos ha llamado la atención, pues un instrumento tan específico para una labor de grabado, no hubiera sido acarreado hasta allí, sino fuera porque existiera una idea consciente de llevar a efecto una tarea para la cual fue concebido. Sí es interesante constatar que raramente se han empleado instrumentos de hoja cortante, como cuchillos o navajas, pues los grosores del trazo superan en más de un 95\% los cinco milímetros de anchura en las siluetas.

A primera vista se extiende ante el espectador una confusa maraña figurativa, sorprendente por la concentración de motivos, que forman un conjunto a la vez denso y complejo, acentuado por las superposiciones y una conservación a veces muy parcial, no obstante una observación más detallada nos permite contemplar y aislar las figuras, que en un alto porcentaje resultan reconocibles. Hemos desistido de realizar una estadística sobre el total de elementos representados, por lo difícil que resulta evaluar la cantidad exacta de ideomorfos presentes en la composición, pues muchas se interceptan y entremezclan, creando nuevos diseños completamente abstractos de imposible separación. Así pues hemos trabajado con el número reconocible de ellas, resultando que la mayor presencia corresponde a los motivos cruciformes con 74 elementos de distinta tipología; le suceden los antropomorfos con 32 figuraciones y los zoomorfos con 28. Los signos epigráficos han sido tomados como composiciones y no como elementos aislados, es decir han sido contados como unidades cuando forman parte de unas iniciales o una fecha, totalizando 36 grupos, de los contrario superarían con mucho a todos los demás, con casi 160 signos entre expresiones alfabéticas y numerales

Para referirnos a los motivos dentro de un complejo tan extenso como el que presentan las paredes del conjunto de Monsalud, la forma de señalar a un punto concreto se efectuó de la siguiente manera. A cada aljibe se distinguió con la numeración romana I-II y a cada una de sus paredes con las iniciales correspondientes 
a su situación, en función de su orientación a los puntos cardinales N, S, E y O. En cuanto a los paneles, la superficie de cada pared ha sido dividida en cuadrículas de I m. por I m., ello nos permite referirnos a los motivos sin enturbiar el conglomerado con numeraciones o signos ajenos al mismo, pues con números identificamos los lados superior e inferior de las cuadrículas y con letras los laterales (Fig 2, 3, 4, 5, 6).

\section{TIPOLOGÍA DE LOS MOTIVOS}

Más que una descripción pormenorizada de los paneles cuya composición puede seguirse a través de los calcos, hemos preferido, con el fin de no repetirnos, agruparlos según su tipología, de esta manera pueden reconocerse varias series: antropomorfos, zoomorfos, cruciformes, armas, signos epigráficos y en un apartado de varios, aquellos que aparecen esporádicamente. Aparentemente variado, el repertorio iconográfico presenta una asombrosa coherencia por la recurrencia de ciertos temas o motivos, tales como los personajes armados, los combates, los caballeros o los motivos cruciformes.

\section{I. Antropomorfos}

La variedad en los tipos de antropomorfos son la expresión más clara del empleo de manos distintas en la realización de los mismos. Los más abundantes ajustan su representación al trazado de unas figuras que limitan su corporeidad a un tronco de diseño triangular o rectangular cabeza circular casi sin detalles fisonómicos y miembros inferiores muy cortos, que tiene como resultado, unas figuras totalmente planas, faltas de corporeidad, en la que sólo resaltan como excepción, los motivos asociados a ellas, bien sean armas u otros instrumentos. Son las que se conectan a casi toda la serie de jinetes y peones como los que en la pared (I-N) enarbolan lanzas, escudos y espadas; constituyendo una curiosa seña de identidad la forma de empuñar las últimas con la mano izquierda, mientras que con la derecha se sujetan las riendas de la montura u otros objetos. A esta serie pertenece también un personaje (I-N; 5B) significado por el extraño paquete o adorno que lleva encima de la cabeza y por la desproporcionada mano que parece tenderse hacia el jinete que tiene delante (Fig. 7 y 8$)$.

A medio camino entre este y el siguiente grupo hemos situado un individuo, al que se le ha dibujado con el torso triangular, las piernas alargadas a doble línea para dar sensación de volumen y con los brazos indistintamente colocados hacia arriba y hacia abajo, en una posición que recuerda a la de una danza (I-N; 5A).

El siguiente grupo de antropomorfos por orden numérico, concierne a unas figuras de gran tamaño, en la que los detalles anatómicos son mucho más expresivos, pues aparte de incluir los rasgos faciales elementales de ojos, nariz o boca, aparecen retratados abusando de una ley de la frontalidad que exige el extraño escorzo en algún personaje, siempre con los brazos en jarras (I-N; 4AB y I-E; I A, 2A). Los detalles del atuendo son más precisos, pudiendo en un caso, reconocerse el uso de un calzado con tacones, tal vez unas botas y un atavío que incluye varios tipos de gorro, siendo extraordinariamente detallista el individuo de la cuadrícula (I-E; $2 A)$, que parece estar tocado de un sombrero de tres picos, mientras que en otros dos da la impresión de que se cubren con morriones. En ambos casos la indumentaria es de tipo militar, hecho contrastado también, porque todos los personajes de este tipo portan armas envainadas, a diferencia de los del primer grupo. En todos los casos son espadas entre las que pueden distinguirse dos tipos de los cuales, un par por lo menos, poseen empuñaduras de lazo y quizá doble gavilán, frente a los de empuñadura sencilla, detalle que acentúa las diferencias entre los personajes, tal vez utilizados simbólicamente como elementos de una confrontación menos historiada que la de los guerreros a caballo.

Con una mayor economía de rasgos, pueden reconocerse una tercera categoría de personajes con una morfología similar a la de los clásicos antropomorfos de la pintura esquemática, donde la figura humana queda reducida mediante la línea a un cuerpo alargado con los brazos en cruz y un trazo axial bifurcado 
en arco para formar las piernas (I-E; $2 A B$ ), siendo posible que algún caso entre los cruciformes, como se ha comprobado en más de un conjunto, entre también en la categoría de las representaciones de un personaje.

Quedan por último unos casos aislados que traducen la imagen de un ser, a través de una careta, de una cabeza de perfil con un silueteado rudimentario o con los miembros apenas insinuados.

\subsection{Zoomorfos}

En la iconografía de los animales grabados de Monsalud, es de hacer notar la presencia de dieciocho équidos de un total de veintiocho zoomorfos, entre los cuales, aún podríamos contar algún caballo más, pero el estado de extrema simplificación nos impide aventurarlo. Sí se reconoce la forma recortada de un pez, dos aves, tal vez un bóvido y un cérvido (Fig.7).

El modelo de representación de los équidos se ajusta a una especie donde las orejas estarían indicadas por dos trazos perpendiculares a la frente, que se mantiene ligeramente baja en línea recta con el tronco, para indicar de forma convencional, igual que las patas siempre adelantadas, el estado del animal en movimiento. Muy a tener en cuenta es la desenvoltura en el trazo, los cuidados detalles de la ejecución de la cola, el hocico o las pezuñas, donde se han extremado las medidas para no salirse del marco del dibujo; también el esmero puesto en los atalajes de la caballería, es decir en las riendas, gualdrapas, la silla de montar, donde se identifica un tipo con los borrones o arzones delantero y trasero muy levantados, que entrará en desuso a partir del siglo $\mathrm{XVI}$. Sólo en las figuras de los jinetes se constata un desinterés, contrastando la buena ejecución de las monturas, con el del personaje que lo monta reducido a la mínima expresión.
Todos estos detalles nos han llevado a reconocer al artista de una serie al que otros van a imitar añadiendo nuevas figuras de équidos de menor calidad que crean una interferencia en la escena.

Al artífice de los guerreros debe de corresponder también el caballo del Aljibe II, la figura de mayor tamaño de cuantas han sido plasmadas. Como rasgos a destacar, presenta, patas cortas levadas para indicar un paso elegante al trote, cola baja y alargada, cuerpo globular de percherón y cabeza de gran tamaño no terminada y dos leves líneas verticales sobre la grupa que interpretamos como una simplificación de la silla de montar.

El pez, también el en Aljibe II es de estilo minimalista, con separación de la cabeza, pero cola y aletas sin concretar. El resto, si bien los hemos encasillado como aves, cérvido y toro, son más que dudosos, igual que la serie de cuadrúpedos sin jinete, que bien podrían tratarse de cualquier otro representante de la fauna del entorno.

\subsection{Cruciformes}

La reiterada presencia de estos motivos en yacimientos rupestres, es lo que ha llevado a algunos investigadores a plantearse la necesidad de recogerlos en unas tablas tipológicas (FORTEA, 1970-71; CRESSIER, 1986; SOLO DE ZALDIVAR, 1991; BALLESTEROS Y RIBEIRO, 1999) como paso previo y necesario a un estudio en el que debía establecerse una clara diferenciación entre otros de similar apariencia pero con una filiación prehistórica ${ }^{5}$.

Todos los grabados presentes en Monsalud reproducen el mismo esquema formal que otros inscritos en diferentes sillares de edificios religiosos y rocas de la región, con elementos que no impiden intentar una contextualización coherente de las mismas.

5 En el I Congrés Internacional de Gravats Rupestres I Murals celebrado el año 1992 en Lérida, J.A. Gómez Barrera al tratar de los primeros ejemplos de grabados murales en la provincia de Soria, ya advirtió del escaso margen bibliográfico que la investigación había concedido los grabados murales históricos. 
Dentro de los tipos que hemos aislado, el más numeroso está encabezado por versiones latinas y griegas de gran tamaño con cruces inscritas dentro de otras que ocupan una buena parte de la superficie, le siguen otras versiones de la misma tipología dibujadas con dos simples trazos y a continuación la serie más interesante de cruces sobre la "imago mundi" (I-S; I5B), con gólgota (II-O; 9A), de cruces trinitarias (I-N; 5A/II-0; I | A), compuestas (I-E; I b), una de Caravaca dudosa ( I-E; I A) y para cerrar, con un pequeño grupo en las que la cruz forma parte de un complejo emparrillado ( I-E; 3AB), inscritas dentro de un marco ( $1-O ; 9 A)$ y otras especies inidentificables que son el resultado de intersecciones con otros motivos o añadidos aleatorios (Fig. 9).

\subsection{Armas}

El arsenal de armas, es de lo más interesante de todo el conglomerado graffilico, tal vez porque se ha insistido en el detalle de alguno de los objetos. Ya nos hemos referido a los tipos de espadas sencillas con la empuñadura transversal que sostienen una suerte de soldados, pero tan esquemáticas que no permiten mayores precisiones, igual que los escudos, lanza y arco que acompañan a otros, todo lo contrario que las espadas de las figuras de mayor tamaño, que sí ofrecen a través de las empuñaduras, la posibilidad de aproximarnos a una interpretación más clara, como ya hemos adelantado.

La más importante, por su fidelidad a un modelo original es una ballesta de la cuadrícula (I-N; 7A), que muestra en todo detalle la presencia de una estribera pequeña en la punta para armarla, una larga cureña, un arco o verga de hierro muy cerrado, una llave que forma parte de un fiel a un brazo mayor que recula hasta el extremo de la cureña.

\subsection{Signos epigráficos}

Casi todos los signos alfabéticos reflejan la identidad abreviada de los visitantes del sitio, igual que los numerales el tiempo en que deja- ron constancia de una presencia. Nuestra opinión, como dejaremos sentado al estudiar el apartado cronológico, es que son un producto reciente, de hecho la moda de indicar el nombre de una persona de forma abreviada es producto de la modernidad, y el hecho que mejor lo demuestra es la costumbre de emparejarlas con fechas, que en el caso de nuestros aljibes la más antigua sólo llega a I830. Las letras son latinas capitales a imitación de otras letras de molde de imprenta.

La única excepción del caso podría presentarse en el Aljibe II, donde debajo del gran caballo del friso (II-N; 6A) puede leerse "Famoso", aludiendo tal vez al nombre del animal. De los autores, no tenemos ninguna noticia, salvo los que señala un juego de iniciales con una cruz debajo de la $\mathrm{H}$, conocido por su empleo como símbolo del escudo de la Compañía de Jesús (Fig. 10).

\subsection{Varios}

En el grupo de varios hemos englobado una serie de símbolos cuya expresión entendemos, quizá porque al coincidir en otros complejos, nos resultan más familiares; ello no quiere decir que puedan en el futuro reconocerse algunos más.

Ninguno de los que citaremos son abundantes, aparecen esporádicamente en la narración como la solitaria pentalfa de la pared sur del aljibe I (I-S; I 4A-B), los motivos circulares O anillos irregulares (II-S; I3A / I-S; I4A, I3B/ I-N; 4A), las herraduras (I-S; 12 y 13 A), escaleriformes (II-E; I A), o los que denominamos emparrillados (I-N; A7, A I2, B6, B I I ), unas estructuras de líneas que componen figuras reticuladas, en la que se mezclan motivos geométricos con posibles cruciformes, signos alfabéticos o sencillamente copian objetos en perspectivas que no permiten adivinar de lo que se trata; algunos llegan a ser tan complejos que su laberinto de no haber sido por el empleo del hormigón hidráulico como soporte, en vez de la roca, hubiera dado pie a considerarlos como elaboraciones mucho más antiguas (Fig. I I). 


\section{APUNTES PARA UNA INTERPRETACIÓN}

A pesar de no ser escasos los estudios del Arte Rupestre extremeño, si puede decirse que no ha habido ninguno que abunde en la cuestión de los graffiti, tal vez la explicación no esté más que en la diferencia de soporte y en la suposición de que los grabados de época histórica tienen una fácil traducción, una cuestión que se halla bastante lejos de la realidad como vamos a tratar de demostrar en este.

\section{I. Cruces}

En Extremadura su abundancia y variedad se incrementa exponencialmente a partir de las fechas de la reconquista como símbolo de la influencia y poder de la Iglesia Católica, que no sólo es capaz de llegar hasta los rincones más remotos, sino de hacer acto de presencia incluso en los aspectos más cotidianos. Los grabados no son más que un testimonio de la creciente influencia social destinada a borrar la huellas de cualquier paganismo subyacente, tanto, que el afán por santificar lugares concretos de la geografía es una práctica corriente y reconocida por toda Extremadura. Un ejemplo evidente lo podemos contemplar en el yacimiento de Las Cañadas en Valverde del Fresno (Cáceres) (Fig. I4), donde la asociación de muchas de ellas a sepulcros excavados en la roca, tenidos tradicionalmente como sepulcros de "moros", proporciona el móvil necesario para exorcizar el espacio funerario multiplicando la presencia de cruces para así devolver a la roca la esencia espiritual cristiana, sin que paradójicamente el acto deje de ser una idolatría.

Sospechamos que esta costumbre arraigada desde la temprana Edad Media en los reinos cristianos del norte, según se constata en innumerables abrigos y eremitorios dispersos por la geografía aledaña al Duero, se va a con- vertir en un comportamiento tremendamente ritualizado, pues el mismo proceder vamos a observar en el castillo de Alija (Cáceres), por citar otro yacimiento con una cronología medieval $(X-X \mid I I)$, pero que se multiplica sobre todo si nos referimos a edificios religiosos, en su mayoría ermitas, edificadas en una buena parte sobre vestigios que los inmigrantes que proceden allende las fronteras del Sistema Central van a considerar paganos.

Existe no obstante un apartado de interpretación de la simbología cruciforme que no podemos dejar de tener en cuenta, y es el que se relaciona con los amojonamientos, marcas de propiedad o deslindes, son los petroglifos de término de los que habla el investigador orensano J. Ferro (1952), que ponía en cuestión entre otras cosas, la adscripción mecánica de cualquier grabado en soporte pétreo como prehistórico, algo que parece dejar muy claros los de Monsalud, la ermita de San Salvador de Cuacos de Yuste, los de términos de Jarandilla, San Cristobal de Valdemorales, etc.

Sobre esta línea no resulta difícil encontrar documentos en los archivos municipales relativos a los itinerarios de deslindes y amonjonamientos, con una llamada de atención a la cantidad de veces en la que la marca de una cruz se cita como instrumento de separación ${ }^{6}$, equiparándose claramente con esta costumbre las ocho cruces que separan los términos de Jarandilla, Losar y Robledillo de la Vera; los cuatro conjuntos alineados en el pico de San Cristobal en Valdemorales, las de San Juan el Alto en Santa Cruz de la Sierra (Fig. I3) y quizá muchas de las que tenemos en Monsalud, disfrazada entre esa maraña de posibilidades interpretativas.

Setenta y cuatro cruces, no obstante son muchas cruces para que en el caso de Monsalud quede constancia de la existencia de un

6 "....los mojones nuevos que son e fueron fallados dentro de la heredad e defesa de carmonita heredad de dicho concejo que sean ebulsos arruinados e derribados donde están e nuevamente fueran puestos e desfechas las cruces de los arboles e los mojones antygua de la mojonera vieja e dicho alcornoque una cruz e cerca dende en un valle otro mojon e dende en su derecho otro mojon en un teso cerca de unas encinas e en su derecho otro mojon a pie de un alcornoque sobre tres cantos labrados e en el dicho alcornoque una crus cerca de un villar e en el dicho villar una cruz "(Floriano, 1934: |457.21,XI), 
hito de demarcación territorial, de hecho en los deslindes actuales de término no parece que el castillo lo hallan utilizado de hito, pues todas las lindes que hemos podido conocer del sitio esquivan las cumbres. Más nos inclinamos a creer que es la propia identificación del sitio como primitivo núcleo musulmán lo que mueve a los realizadores de los grabados a la recristianización mediante el bautismo del lugar con el símbolo de la cruz en sus diferentes versiones. Así parece ocurrir también en Galicia, donde las cruces invaden incluso planos rocosos al aire libre, a veces tantas, como en la Pena do Altar de la Punta Herminia en La Coruña, que semeja un retablo (COSTAS Y PEREIRA, 1998: 160), superponiéndose a grabados prehistóricos, de término, votivas o de peregrinación, convirtiendo esa región en una de las que más uso han hecho de este símbolo en la Península.

\subsection{Antropomorfos y zoomorfos}

Los frisos con figuras humanas, ya sean soldados, caballos o caballeros, desde la Baja Edad Media constituyen uno de los temas preferentes dentro la iconografía graffítica. Su presencia suele coincidir con la geografía de los castillos de la Península, por lo que sus representaciones van a estar vinculadas normalmente al ámbito militar.

En Monsalud reconocemos una escena subyacente entre los dibujos del Aljibe I, y la componen una buena parte de las figuras montadas y algunos guerreros a pie. Esta afirmación como se ha comentado en la descripción tipológica de los antropomorfos, no sólo la ponen de manifiesto su unidad canónica o el hecho de estar sujetos a una escala muy similar, sino la repartición-orientación de los mismos, en lo que al final nos parece un friso continuo pese a que las paredes se plieguen en ángulo. Se trataría de una narración de contenido bélico, en la que caballeros y peones marchan hacia un frente que se encuentra a la izquierda del espectador, sentido fácilmente deducible por la disposición de los pies de los personajes o la cabeza de las monturas; sólo en un caso, al final del recorrido, aparecen girados en sentido contrario un équido desmontado y un jinete con los brazos levantados, actitud que a nuestro juicio tiene la intención de informar sobre la presencia de un enemigo derrotado. La masiva presencia de cruces que jalonan el camino del ejército representado aludirían de este modo y claramente a las huestes cristianas (Fig 7 y 8).

Aunque en Extremadura, esta es la primera vez que se reconoce una escena semejante, se pueden traer a colación muchos casos que dan una idea de la popularidad alcanzada. En el castillo de Castellfollit de Ruibregós, las formas se debaten en torno a la idea de representar dos bandos librando una batalla, en pleno movimiento, con los caballos levantando las patas, los ballesteros disparando flechas (CARBONELL, 1981: 302) y en el castillo de Petrer en Alicante (NAVARRO, 1993: 109), de nuevo con ballesteros, escaleriformes, pentalfas, etc.

Narraciones de este tipo no son raras, de hecho es muy común contemplar graffiti con una disposición similar, ya sea con caballería o con barcos. Un caso elocuente queda recogido en los grafitos medievales del castillo de Denla en Alicante, donde una pequeña armada de barcos sustituye a la caballen'a en una sucesión de naves orientadas de derecha a izquierda (GISBERT, 1984), que sugieren el desarrollo de una batalla naval, lo mismo que en otros se sustituye por una escena de caza.

Conocemos también un grupo con representaciones afines a las que aquí se tratan, pero que hasta ahora hemos mantenido aparte, sencillamente porque no aparecen en paredes o sillares de edificios, sino en cuevas, abrigos o rocas al aire libre. Hablamos de pinturas y grabados que tiene como nexo común la presencia de guerreros armados. Entre las primeras podemos citar los del covacho abulense de Ojos Albos (ALVARO, 1974: 16), donde figuras tan esquemáticas como las que se encuentran presentes en los aljibes de Monsalud, portan espadas, arcos y escudos redondos. Entre los segundos, pueden servir como ejemplo los de Domingo García (Segovia); allí aparecen de nuevo figuras humanas componiendo escenas con sus protagonistas bien pertrechados con escudos, lanzas, cascos, espadas largas, arcos, unas veces a pie y otra a lomos de sus caba- 
I I Os (GOMEZ, 1993: 208 Y 223). Ambos casos se interpretan como un producto tardoesquemático, lo que equivale a considerar tales manifestaciones, exentas de contexto arqueológico alguno, como un producto de las sociedades del Bronce Final o de la Edad del Hierro.

Esas afirmaciones a la luz de los paralelismos con inmuebles de cronología histórica, es evidente que no dejan de ser estimaciones arbitrarias,'ya que el soporte, que es el que se ha tenido más en cuenta a la hora de fechar ciertos motivos, no deja de ser algo accidental, pues tal y como se ha demostrado con los cruciformes, que pueden aparecer indistintamente en muros o en roca, grabados o pintados, otros motivos también pueden hacerlo. Esto da pie a pensar en primer lugar, que los episodios con guerreros y especialmente por su abundancia la figura del jinete, constituyen uno de las temas preferentes de las representaciones parietales medievales e incluso posteriores y como tales, muchas de que hasta ahora han sido arrojadas al cajón de la Prehistoria, deben ser rescatadas como piezas posibles de un momento mucho más tardío del Arte Rupestre, sirviendo para esta reflexión la que realiza también Gómez Barrera sobre algunas figuras de cuadrúpedos del barranco de la Mata (Tiermes, Soria), grabadas en acantilados y farallones rocosos, similares a las halladas entre figuras de la misma cuerda en los muros de la galería porticada de una ermita en la misma localidad o las que pueden inferirse del estudio de una roca localizada recientemente en Navalvillar de lbor (Cáceres) con un cuadro de personajes tocados con cascos cónicos y espadas, (GONZALEZ, 2000: 95) de diseño típicamente graffítico (Fig I2), en la que se reconoce su pertenencia al mundo medieval.

En el capítulo de zoomorfos, no podemos olvidar tampoco la figura del pez (II-O; 9A). Su posición en un lugar central, rodeada de todo un muestrario de cruces, sobre otra cruz, que es a medias cruz y persona, con un animal, tal vez una oveja, colocada sus pies, parece albergar de una forma infantil toda una simbología cristiana del buen pastor dispensando a través de la cruz, sus cualidades redentoras. Esta imagen del pez se repite en contexto muy próximos, caso del castillo de Villalba y castillo de Alange ${ }^{7}$.

\subsection{La Pentalfa}

Al primero de la serie mencionada en el capítulo de -varios- se le conoce bastante bien, pues independientemente de su milenario y reconocido origen ha padecido una evolución que ha trastocado su significado, sobre todo a partir de la Edad Media, en cuyo ambiente debemos centrarnos. Aquí serán populares como amuletos o talismanes con virtudes profilácticas, por lo que no será raro encontrarlos en objetos de la metalistería popular, objetos utilitarios e incluso en construcciones. Los más conocidos de la región se encuentran en las peñas hurdanas de Aceitunilla y la Huetre (SEVILLANO, 1991:16 Y 50), en los sillares del Castillo de San Juan de Mascoras en Santibañez el Alto y en la argamasa que cubre las paredes exteriores e las iglesias de san Andrés en Navalmoral de la Mata y La Piñuela de Casas de Miravete. Su dispersión empero es enorme, por lo que nos limitaremos a citar ejemplos que evidencien una relación más directa entre contextos; en este sentido se conocen en el castillo de Jubera en la Rioja (FERNANDEZ et alii: 1987: 4I0), en las paredes de los acantilados de Tiermes (GOMEZBARRERA, 1992: 164), curiosamente acompañando jinetes con largas picas, en la Lonja y la Seu de Mallorca (GONZALEZ, 1989: 176) acompañada de cruces con gólgota, en el castillo de la Mola en Novelda (NAVARRO, 1993:4I), en la superficie de una roca en Monte da Penha (Rianxo;, La Coruña) de nuevo junto a cruces, esteliformes, círculos, etc.; en baldosas de pizarra de Vascos (IZQUIERDO, 1994: 52), etc.

7 Nuevos graffiti de Alange, Villalba, del propio castillo de la localidad de Nogales y los existentes en las iglesias de la Parra y La Morera, quedan para un posterior estudio. 


\subsection{Herraduras}

Más raros en el programa ornamental de los dos aljibes son las herraduras. Hasta hace unos años era muy problemático sintetizar la cronología de esta grafía, pero la masiva aportación de investigaciones que la incluyen en los estudios del Arte Rupestre facilita aún más su comprensión, sin que por ello podamos decir que hallamos llegado aún a la solución del problema.

La discusión se ha originado en torno a dos de los planteamientos que ya son habituales en la investigación del fenómeno -su origen y significado-. Historiando la cuestión nos encontramos con dos posturas antagónicas muy bien definidas, por un lado los que mantienen la antigüedad de este símbolo y por otro los que creen firmemente en su modernidad. Un trabajo de P Bueno y R. de Balbín (1997: 96), en el que se da cuenta de la existencia de motivos en forma de $U$ en las losas del sepulcro megalítico badajocense de Granja de Toniñuelo, además de en otros dólmenes de Portugal, o el que en sentido contrario elaboró E Cressier (1986), haciendo hincapié en las herraduras que pueblan las paredes de argamasa en castillos medievales del sur de Andalucía, puede servir de ejemplo sobre lo dicho.

De la lectura de ambos, lo que se deduce es que a nivel general, el problema seguirá existiendo siempre que halla quién considere a la grafía como el producto exclusivo de un tiempo concreto, cuando por la misma razón, otros símbolos de diseño tan sencillo, pueden nacer; como ya dijo A. Beltrán (1989:35) en cualquier tiempo sin necesidad de establecer relaciones de causalidad o de imitación. La solución estriba en contemplar a cada conjunto como un objetivo separado del contexto general, echando mano a todas las pistas que puedan proporcionar su entorno, la asociación a otros motivos, paralelos iconográficos, el lugar de inserción, etc.

Examinando los casos extremeños, desde las representaciones en los aljibes de Monsalud a los de la Peña del Molde (Mesegal), Las Tarabillas (La Huerta), Los Bonales (Cambroncino),
Regato del Chorrero (Sauceda), La Pimpollosa (Sauceda), Collado de Matalascabras (Sauceda), Esparragosillo (Alcántara), Las Alberguerías (Cañamero), La Herradura (Monroy), Alija y Cancho Castillo (Peraleda de San Román) (GONZALEZY QUIIADA, 199I), e incluso la Piedra de las Herraduras de Alburquerque (Badajoz) (LOPEZ CANO, |991: 5), nos encontramos que algunos casos se pueden aislar en función de características particulares.

De la Herradura de Monroy y de los de la Sauceda muy poco pueden decirse que no sea por inferencia, pero acerca de los demás, nos encontramos con una presencia redundante de cruciformes que en su mayoría hemos reconocido como producto propio del medievo. No es una conducta original, pues la concurrencia de tales motivos ha sido reconocida entre graffitis cristianos de los aljibes de las fortalezas de Tricia la Vieja y la Sierra de Berja (CRESSIER, 1986: 281 ), bien junto a tipos de cruces normalizadas o con pies de bulbo redondo que vemos en la mayoría de los sitios citados.

La posición excéntrica de las herraduras de Las Alberguerías o el Esparragosillo, por si cupiera alguna duda sobre la simultaneidad con otros motivos de sabor arcaico, creo que puede utilizarse como un argumento más para defender su realización "a posteriori", lo mismo que la inclusión de una omega en el Collado de Matalascabras, por mucho que ciertos símbolos escutiformes del mismo conjunto, nos recuerden a las placas acéfalas como las que podemos encontrar en el Peñón de Hornachos. Escutiformes que reiteran su presencia también, en la Peña del Guisaero (Albacete) (MAYA, 1977: 159), de nuevo junto a cruces y herraduras o en los acantilados sorianos, donde junto a cruciformes llegan a ser el tema más representado entre los conjuntos grabados al aire libre (GOMEZBARRERA, 1992: 294).

La difusión tan amplia de este motivo además, la creemos sintomática de un fenómeno mucho más general, que camina parejo al de los cruciformes. Un repaso a los lugares más conocidos siembra los cuatro puntos cardinales de la Península con paneles protagonizados por este motivo. En Galicia, son ejemplariza- 
bles los casos de Gudiña, Cortegada de Miño, etc.; en Portugal, podemos citar las Peñas de Eira dos Mouros, Outeiro do Machado, Bemfelta, Linhares, Entre Os Ríos y Triple Mairós, con combinaciones sucesivas de cruces, círculos, herraduras (MARTINEZ, 1950: 27I), idénticas a las que progresan hacia el sur, vistas en la Pedra das Gamela (Évora), etc., (ANATI, 1966: 251). Les siguen los de Cataluña con la Rocas das Ferradures (Capafonts, Tarragona), hacia el sur en Tíjola (Almería), hacia Sevilla con una representación en El Esparragal de Gerena y así a través de la Meseta, en la Cañada del Monte (Retortillo, Soria), Canales de Molina (Guadalajara), Barranco de la Mata (Soria) (GOMEZ BARRERA, 1992: 137), etc.

En cuanto a los motivos de herradura su encasillamiento en un tiempo concreto facilita su labor de interpretación, o mejor sería decir, que el significado que tradicionalmente se le ha atribuido, coayuda precisamente en ese encasillamiento. Prescindiendo de interpretaciones esperpénticas entre las que sin base ni fundamento se ha dicho que era un sistema filológico sui géneris, que delataba la afluencia de fieles a un lugar dedicado al culto al cerdo (SANTOS Y AZEVEDO, 1960: 43), a la interpretación de esquematizaciones femeninas de J. Cabré, se ha recorrido un largo camino en el que se han tenido en cuenta desde la tradición a la bibliografía histórica. Ambas apuntan hacia aquellos lugares en los que se señala un hecho, en el que normalmente ha tenido lugar una intervención milagrosa; al respecto todavía puede verse en San Vicente de Ávila, tras una reja y un cristal, una gran herradura grabada que da fe de un milagro relacionado con la mula de San Pedro del Barco, algo parecido a lo que nos relata M. Murillo (1987: 51), con respecto a otra herradura grabada en las cercanías de la ermita de la patrona de Gerena, que señala el lugar donde un caballo desbocado detuvo su carrera, al implorar su jinete la ayuda de la Virgen y así en Extremadura otros sitios. No es extraño tampoco que se hallan utilizado como símbolos profilácticos como señala Cressier, de hecho sigue siendo un símbolo proveedor de suerte; igualmente en la cultura popular extremeña, existe una tradición de veneración de sitios donde supuestamente se apareció Santiago
Apostol a caballo, pasó la mula de la Virgen, se produjo algún milagro, etc. Un caso bastante claro es el que se halla en una jamba de la puerta de Santiago en Trujillo, donde una cruz protegida por una herradura aparece en la leyenda como la marca de una coz del caballo del Santo. Tienen pues estas reproducciones un carácter recordatorio, de veneración y de salvaguarda, perfectamente reconocido en la tradición cristiana sincretizada de la pagana.

\subsection{Emparrillados}

Por emparrillados entendemos unos símbolos que acogen a diversas estructuras rectangulares o subrectangulares con compartimentaciones en su interior; rehuimos del concepto de tectiformes, que en la prehistoria se les suele aplicar a figuras trazadas a base de formas geométricas de difícil interpretación. Un repaso a la interpretación de estos signos, por lo que han dado en pesar en lo que pueden representar, resulta bastante chocante, pues se ha hablado de construcciones, cercados, redes, etc. un conjunto de interpretaciones bastante dudosas cuando se trata sobre todo de producciones prehistóricas, y que siguen siendo igualmente inciertas en tiempos históricos. No obstante su significado durante un tiempo tuvo que ser compartido, porque es posible encontrar signos idénticos en conjuntos diferentes y alejados entre sí. Por citar lugares cerrados nos referiremos a Peña Castillo (Peraleda de San Román), un lugar donde aún quedan los restos de una construcción sobre una peña, que según la tradición fue atalaya mora, allí entre grabados prehistóricos de cazoletas se intercalan herraduras, cruces y otros signos, entre los cuales uno que semeja la caja de un carro de vara visto en perspectiva aérea se emparentan con los otros que abundan en la pared $\mathrm{N}$ y $\mathrm{O}$ de Monsalud y que también hemos visto fuera de la región en la Cueva Grande en Oteruelos (Soria) (ORTEGO, 1974: 213).

\subsection{Escaleriformes}

Dentro del grupo de geométricos hay una variedad que hemos considerado interesante aislar, aunque sólo aparece en una ocasión (II- E; I A); se trata de un escaleriforme, un sím- 
bolo que hemos reconocido en rocas al aire libre del norte de la región, formando parte de complejas composiciones lineales con un vocabulario de imágenes muy cambiante, que permiten con una misma base geométrica diseñar composiciones diferentes, por lo que a excepción de arcos y flechas, motivos circulares, reticulados, triángulos alabardados y escaleriformes, resulta muy difícil discernir que partes componen ese puzzle. Este de Monsalud no es el caso, pero quizá en un futuro cercano hallazgos similares dentro de conjuntos con este símbolo, ayuden a proporcionar una cronología a esos complejos, para los que se han aventurado hipótesis con escaso fundamento.

Si se quieren comparar los escaleriformes, estos se hallan presentes en Campos del Agua (Alcántara), Vaciancha IV (Cañamero) (Fig. I5), curiosamente asociados a cruces latinas con Gólgota, Puerto del Gamo (Mohedas), Peña Pintá del Arromoro (Vegas de Corla), Huerta del Cura (Aceitunilla), Vaciancha V (Aldeacentenera) y en la peña de La Rueda en el pueblo salmantino de Navarredonda de la Rinconada. Este último grabado, es a nuestro juicio el más interesante, porque aparte de representar un damero junto a podomorfos, contiene escaleriformes (uno de ellos con cinco peldaños) que se asocian a varios équidos. Uno de los caballos lleva a la grupa un jinete que porta en la mano izquierda una lanza, mientras que con la derecha sujeta unas riendas marcadas con todo detalle, igual que el resto de los correajes, recreando un estereotipo que ya nos suena familiar en el estilo de Monsalud, igual que nos resulta conocida la técnica de relleno del interior del cuerpo del jinete, idéntica a la de las figuras de Navalvillar de Ibor. Ma. C. Sevillano (199|: 60) los considera de época medieval, lo que quizá podamos corroborar a la vista de las relaciones que se establecen entre ellos.

Respecto al significado, sin desdeñar otras interpretaciones que deben ser contempladas en su propio contexto, la explicación que nos parece más viable es la que nos remite al ambiente religioso que predican la inmensa mayoría de los símbolos. En base a esta idea hemos rastreado dentro de las iglesias esta posible iconografía y nos hemos encontrado que con relativa frecuencia, junto a las imágenes de Cristo crucificado, bien sea en piedra, bordado o grabados se añaden elementos tales como el martillo, las tenazas, los clavos y la escalera, símbolos del sacrificio en la cruz, con lo que su presencia en el aljibe II de la escalera de cinco peldaños, no dejaría de ser un mero complemento de la idea de redención que impregna el sitio.

\subsection{Círculos o composiciones de círculos}

A este grupo pertenecen círculos simples o formas ovales, normalmente con los contornos y trazado bastante irregulares (II-S; I 3A / I-S; I4A, I3B/ I-N; 4A). Esta forma se ha prestado según contextos a mil interpretaciones, pero está claro que en el nuestro, sin asociación clara a motivos concretos, va a resultar difícil de dilucidar argumentalmente, si no es por comparación con otros conjuntos, por ejemplo los que a lo largo de la cuerda del pico de San Cristobal en la Sierra de Montánchez, van desde el coronamiento hasta el collado más próximo. En ese lugar, entre las figuras que constituyen el soporte gráfico de cuatro paneles, se repiten constantemente cruces griegas, latinas con bulbo, omegas, herraduras, alfabetiformes y círculos; su dispersión en torno a un lugar que la tradición relaciona con unos hechos que supuestamente tienen que ver con la liberación de estas tierras en la reconquista, gracias a una estratagema de los cristianos, que habían encomendado su éxito al santo bajo cuyo patronazgo se construirá en el s. XV una ermita, constituyen, siempre según la leyenda, un testimonio en favor de la liberación de los cautivos, en la que los círculos desempeñan el papel de instrumentos votivos de las anillas o argollas a las que se encontraban encadenados. Conviene recordar por la importancia que tiene las relaciones contextuales, que a escasa distancia del pico de San Cristobal se alzaba sobre el pico del Castilijillo otro castillo con dos aljibes, tan arruinado como el de Monsalud y a juzgar por la cerámica, de la misma época. 


\section{CRONOLOGÍAS DOCUMENTADAS A TRAVÉS DE LOS GRAFFITI}

Como consecuencia de numerosas superposiciones de todos los temas, determinados motivos resultan más difíciles de fechar con plena exactitud, pues como suele ocurrir en este tipo de estancias abiertas, los paneles van incrementando su gramática decorativa por recurrencia de los grabadores, es decir que no se ha partido de una idea previa para diseñar todo el programa, sino que los motivos son el resultado de añadidos en razón de la frecuentación del sitio, sirviendo como demostración plausible de lo dicho, ciertas fechas grabadas con más de un siglo de diferencia.

No obstante existen unos elementos que debidamente conjugados pueden estrechar el margen cronológico de gran parte de los grabados. Para ello lo primero que ha de tenerse en cuenta, es la datación "ante quem" del palimsepto, obtenida a partir de criterios puramente arqueológicos de contextualización de materiales, de tipología arquitectónica, etc.. La evidencia de que las construcciones sobre las que se encuentran los grabados poseen un tiempo de realización aproximado de tres siglos, los comprendidos entre el s. IX y el XII, constituye nuestro punto de partida, aunque esto no signifique que tengamos que contar a partir de ese momento, pues si tenemos en cuenta que los dos edificios en cuestión, tenían como función servir de depósito de agua para el mantenimiento de una guarnición y de la población asentada en el sitio, resulta del todo inapropiada la realización de trazos tan profundos en el enlucido de argamasa como los que aquí encontramos, porque hubieran comprometido seriamente la impermeabilidad de los recipientes. Lo natural será entonces que la base de datación se sitúe lógicamente a partir del momento del abandono y el vaciado de los depósitos, lo que estimamos debió de ocurrir en torno a mediados del XIII, sino antes.

A partir de ese momento se adueñarán de las paredes un repertorio de objetos o de diseños formales que pueden revelarse como herramientas de datación más interesantes, sin desdeñar las posibilidades que nos ofrecen los principios de estratigrafía horizontal. Esto último se refiere a las consideraciones metodológicas que se aplican en los grabados rupestres, según la cual, los primeros esquemas que se ejecutan, tienden a situarse hacia las partes centrales del espacio disponible o aprovechando los mejores planos. Esta mecánica según hemos comprobado varía ligeramente en un muro vertical, donde por razones de posicionamiento del grabador, la banda en la que se intensifica la producción se desplaza hacia arriba a metro y medio de altura con respecto al suelo, coincidiendo con el punto de mayor facilidad de maniobra para el brazo, tal y como queda patente en los paneles del aljibe I, donde si exceptuamos en el que se halla la entrada (lo), con una exposición mínima de dibujos, en el resto, el espacio señalado hasta el arranque de la bóveda, sólo se puede describir como una abigarrada maraña de elementos.

Así en el estudio, según esta inclinación, vamos a encontramos con que en el aljibe I, los paneles N., S. y E., en la banda descrita, se incluyen hasta un $74 \%$ del total de las cruces que podamos encontrar en el recinto, un $84 \%$ de los antropomorfos (peones) y un $71 \%$ de jinetes, mientras que los signos epigráficos por el contrario sólo se hallan en un porcentaje inferior del $20 \%$. Esto, sin extender la generalización, es sintomático de que la mayoría de las iniciales y signos numerales, fueron añadidos en un tiempo posterior a los demás, algo que parece apoyar también el hecho de que la mayoría de ellos busquen los huecos de las esquinas, la banda inferior y las partes más alejadas de la superior, es decir que dentro de la cadena de realizaciones, son los que ostentan una clara condición de periféricos; es más, incluso cuando se insertan en la banda principal suelen interceptar alguna figura. Dos fechas, 1870 y 1830 en el panel E, se superponen parcialmente a las espadas que esgrimen dos jinetes, lo que por una parte refuerza lo dicho y por otra certifica la evidente anterioridad de los guerreros.

Descartada una parte de los grupos, según hemos manejado los principios de la estratigrafía horizontal, resulta a partir de ahora más comprometido determinar que tipo inicia la 
serie, pues en el eje de la composición de cada uno de los tres muros que consideramos, se encuentran motivos distintos que respetan entre sí el espacio más de lo que pueda parecer y además los porcentajes de congregación se aproximan mucho entre ellos. Llegado a este punto los recursos que emplearemos tendrán que ser forzosamente distintos y basados en los detalles y tipos de los objetos y sujetos reconocibles.

Por un lado están las cruces, un símbolo que se viene grabando desde hace casi dos milenios, pero que en el decurso de los mismos ha ido cambiando al compás de la fenomenología histórica, como signo, distintivo, emblema o insignia, algo que al menos en teoría abre la posibilidad de que se pueda obtener una fecha de sus representaciones. Estaciones con grabados rupestres cruciformes se conocen centenares, pero la ambigüedad en la que se desenvuelve su aparición y la relativa poca importancia concedida, ha hecho que se descuidara su estudio y que en el presente carezcamos de un inventario que a escala peninsular contabilice cuantas aparecen en rocas, al aire libre o cuevas y cuantas en edificios históricos, que son los que a la postre nos van a facilitar por paralelismo una aproximación cronológica.

Fortea (1970-7 I: 141-142), aparte de aceptar que efectivamente algunos cruciformes podrían ser signos prehistóricos y otros la muestra de rudimentarias cristianizaciones, busca demostrar sus explicaciones poniendo como ejemplo la cueva de Cholones, donde junto a pinturas esquemáticas, alternaban series de cruciformes y grafitos escritos con letras góticas; igual que al hablar de edificios históricos donde hacen acto de presencia esquemas idénticos a los que recoge en Piedras Huecas (Vilches, Jaén), marcan las canterías de la catedral de Ciudad Rodrigo, en cuyas paredes abundan cruces con imago mundi y cruces sobre gólgota. Ambos tipos deben de ser introducidos ya desde finales del s. XIV, extendiéndose sus representaciones hasta el siglo $X V I I$, según se colige de los graffiti de este tipo recogidos en la Catedral de Mallorca (SERRA, 1986: 921 y Lám. 20) o en la Lonja de la misma ciudad, donde las fechas se concretan más en torno al siglo
XV Más antiguas si parecen las cruces griegas simples, datadas en el mismo lugar entre motivos anteriores al s. XVI, aunque dada la extrema simpleza del motivo debe de observarse una cierta cautela al hacer extensiva esta afirmación. No obstante, se conocen conjuntos que excepcionalmente utilizan los símbolos descritos, incluso en el siglo $X X$, como ha demostrado recientemente P Solo de Zaldívar (|99|) en su estudio sobre el cementerio de Maro en Nerja (Málaga).

En el siglo XIV detectamos la presencia de cruces trinitarias en edificios castellanos y gallegos no anteriores al siglo XI. con un fuerte desarrollo entre los siglos XIII-XIV. (COSTAS Y PEREIRA, 1998: (5I). Un caso no muy distinto es el de las cruces inscritas o las cruces con pie, de las que Costas y Pereira realizan un extenso inventario.

En otro capítulo abordamos a los antropomorfos, y entre los mismos, una serie que presenta un diseño triangular para la representación del tronco al que se ensamblan los miembros esquemáticamente delineados mediante trazos paralelos y una cabeza en la que el rostro, si aparece, queda reducido a puntos y rayas para simular las facciones. No ofrecen por sí mismos una cronología, pero dentro de los cánones graffiticos, es la fórmula más socorrida dentro de las representaciones antiguas, de hecho, aunque pueda parecer lejana, es fácil rastrearla en numerosos castillos de la marca catalana, y ponemos como ejemplo el Castels de'Oroners (BERTRAN, 1986:125), donde la tradición de estudios sobre grafitados tiene mayor arraigo, también sucede lo mismo en los taifas levantinos con ejemplares similares en los castillos de Petrer (NAVARRO: 1993: 103) y en ermitas de castellanas de finales del románico.

Dentro de las armas, hemos reconocido en los dos grupos de figuras que las portan detalles muy importantes capaces de añadir interés a la cronología. El primer grupo incluye a los escudos, espadas de guerra de hoja larga con una guarda de un solo travesaño, lanzas y ballesta, unos implementos que teniendo en cuenta el tiempo a partir del cual comen- 
zaron a grabarse, debe coincidir entre los siglos XIV y como muy tarde el XV, basándonos en el hecho de que el escudo, especialmente la adarga, así denominado al escudo redondo, es un arma defensiva que comienza a perder importancia en España durante el s. XIII, siendo usado solamente en justas y torneos, siempre y cuando la ejecución de las mismas no hubiese sido objeto de una historia que aquí se rememora después de mucho tiempo y que tendría como objetivo narrar el final de los ocupantes de la fortaleza, en ese caso, puede que incluso aparezca como una onomástica tardía. No obstante no creemos que se de esa circunstancia, primero porque el diseño armamentístico se hubiera ajustado a los cánones de la época como lo harán las de los sombreros de tres picos y morriones, típicas en los ambiente que se desarrolla de finales del XVII a mediados del s. XVIII, cuando la espada prácticamente ha perdido su vigencia salvo como elemento distintivo de rango militar. De ese tiempo debe datar también el anagrama de "IHS", introducido por los Jesuitas.

Más precisa es la datación de la ballesta con todo el rosario de detalles con que se nos ofrece. La primera noticia de su representación en Castilla serán en el s. XI, con su presencia en el Beato de Burgo de Osma y San Baudelio de Berlanga (SOLER 2000: 20), pero la adquisición del estribo en nuestro caso, supone un momento avanzado de su evolución. Sumamente apreciada durante la reconquista, fue utilizada indistintamente por tropas cristianas y musulmanas, pero su representación con posterioridad a la publicación de las Cantigas con sus miniados es sumamente rara, resucitando su iconografía con la gran conquista de ultramar época en la que se muestran ballestas que Soler clasifica como tipo III (SOLER, 1990: 220) con estribos parecidos al de Monsalud. Esta variedad de la que hablamos subsistió a pesar de la aparición de las armas de fuego, hasta el último tercio del s. XVI, a partir de esa fecha desaparece como armamento de tropa y sólo se conserva como elemento de deporte. Su 'decadencia es tal que en 1644, Alonso Martínez de Espinar se queja de que en su época se hubiera perdido el arte de fabricarlas (MARTINEZ, 1644).
Por su tipología semejante a la que figura con el n 271 I del catálogo del Museo de Artillería (VALENCIA DE DON JUAN, 1898: 175) nos parece que debemos situar su fabricación en las postrimerías del siglo XIV, tiempo en torno al cual se ha generalizado por toda Europa un modelo con la cureña muy alargada. Pero otras fuentes iconográficas, principalmente un cuadro de Gregorio Lopes con los pormenores del martirio de San Sebastián (BARROCA, 2000: I l 0) mostrando un soldado portando una ballesta nos aconsejan adelantar su posible datación hasta el segundo cuarto del siglo XVI, fecha aproximada del cuadro. Las razones se hallan en la extraordinaria fidelidad y paralelismo del arma representada con la de Monsalud. En ambas la llave se monta en ángulo recto, el fiel se prolonga hasta el final de la cureña y el estribo redondeado es tan pequeño, que su destino, parece más apropiado para la suspensión del virote, que para la carga del arma, como puede apreciarse en el cuadro; siendo este detalle abundante en ballestas de la misma época, en la que los arcos trazan más grados y el estribo es casi residual.

Dentro del guarnicionado de los caballos puede observarse con detalle el dibujo de las riendas y a veces la silla. Quizá la más interesante sea la que aparecen en la cuadrícula (IE; $2 \mathrm{~A}$ ), donde un guerrero a caballo, monta sobre una silla con los arzones, traseros y delanteros muy altos. Este singular diseño de montura permite al jinete asentarse sólidamente en la montura (a la jineta) y sujetar la lanza como una garrocha bajo la axila cuando se entra en batalla, al contrario de aquellas sillas con los arzones bajos, de las que resulta fácil descabalgar al jinete; razón por la cual sería adoptada por la caballería andalusí, como parece inferirse de un texto de Ibn.Said al-Magribi (DHINA, 1984: 440) Soler ya las recoge en textos y miniados del siglo XII, por ejemplo la Biblia de San Isidoro (Vol, VII, lam. I4.I), en el s. XII en las pinturas murales del monasterio de Santa María de Val- buena (Valladolid) (SOLER, 1990, Vol III. Lám. 26), pero no es hasta el siglo XIII, cuando se adopta el empleo por la caballería de forma generalizada, más tarde los arzones derivarán en una serie de tipos muy populares en el renacimiento con formas cuadradas y rectangula- 
res, que no coinciden con la forma representada en la figura (IE; 2A), por lo que consideramos el citado s. XIII el momento "ante quem" de nuestra datación.

La representación tan esquemática de los de Monsalud, no permite avanzar demasiado, únicamente aventurar una cronología que tiene su tope a finales del XV y principios del XVI, fechas en las que el tipo de silla dejan de ser utilizadas.

Otro dato que pueden corroborar esa cronología, es la fecha de la fundación de las poblaciones cristianas aledañas, a cuyos habitantes lógicamente hay que atribuir la realización de los grabados. En ese sentido, el núcleo más cercano es el de Nogales, población a cuya demarcación pertenece Monsalud, aquí según las fuentes documentales, la primera fundación data de 1340, si bien se refunda posteriormente en el solar actual en 1438 (MORA-FIGUEROA: 1984), no obstante la presencia de pastores de la Mesta que ocupan ya a finales del siglo XIII esas dehesas, pudieran llevar más atrás el comienzo de las incisiones, de hecho gran parte de estas figuraciones se ponen en conexión con la presencia de pastores en las sierras.

A esas fechas se podrían remitir también los escaleriformes si aceptamos que estas representaciones, las más abundantes en el complejo del Raco Molero (VIÑAS Y SARRIA, 1981: 294 y 298), tiene que ver con la fecha " 498 " grabada junto a ellos en una composición de la que forman parte también cruces y antropomorfos o las pentalfas de la Lonja de Mallorca, bajo una fecha que reza |46I. (GONZALEZ, 1989: 176). Hay que decir que la precisión de la descripción del conjunto de elementos citados no es nueva, así se ha hecho notar en más de una ocasión (CARBONELL et ahi, 1981: 309), pero no se puede probar aunque se trate de una corriente estilística propia de algún momento, de lo contrario las cronologías del castillo catalán de Castellfollit, entre los s. XIII y XIV podrían ser tomadas más en cuenta a la hora de dar por sentada una fecha para los grabados de Monsalud.

\section{CONCLUSIONES}

Pese a lo que parezca, los grabados parietales sobre monumentos islámicos no son algo desconocido, en las provincias de Almería y Granada ya se han elaborado catálogos con los motivos más frecuentes o característicos e incluso comparaciones puntuales entre casos exteriores a las dos provincias. Que los aljibes sean uno de los sitios que con más frecuencia alberguen representaciones, tiene su razón de ser en la posición que ocupan los mismos dentro de una edificación, normalmente a nivel del suelo interior; esto les proporcionaba una gran resistencia, de manera que cuando se derrumbaban casi todas las paredes, estos depósitos, sino quedaban sepultados, permanecían prácticamente intactos. En nuestro caso no se encuentran a nivel del suelo, como ocurre en la mayoría de las lugares, pero con los muros de carga parcialmente enterrados y con contrafuertes, han aguantado más que el resto de las construcciones del cerro, a pesar de que la bóveda de uno de ellos también halla acabado hundiéndose en época reciente, como atestiguan los grabados que continúan bajo los escombros. Cuando alguien accedía al sitio, este era pues uno de los pocos lugares que ofrecía paños en condiciones para dejar su impronta, por eso no es extraño que muchos de los grabados a los que nos hemos referido se encuentren dentro de estos receptáculos. Por tanto la elección es puramente circunstancial, como prueba también el hecho de que una gran mayoría se reparta por estancias tan diversas como una torre, una lonja, una prisión, etc., aunque en Andalucía Cressier reconozca que tuvieron un papel importante como refugios de cristianos o como depósitos durante la rebelión morisca (CRESSIER, 1985: 287), de hecho de los siete monumentos con graffiti que estudia, cuatro son aljibes. C. Barceló, en su intento de clasificación de los graffiti árabes ha llegado a identificar varios casos de aljibes que los contienen, acompañados a veces de signos cristianos posteriores, citando el castillo de Gestalgar (Valencia), el despoblado de Marmuyas (Comares, Málaga), etc (BARCELO: 1997: 133), eso supone que el uso de los mismos como soporte pudiera ser en ocasiones anterior a la reconquista. 
Desconocemos el rango de sus autores, aunque en ocasiones esta práctica se ha puesto en relación con el pastoralismo, con la presencia de eremitorios, etc. Lo único cierto, es que la extensión, $32 \mathrm{~m}^{2}$ en el primer aljibe y $14 \mathrm{~m}^{2}$ en el segundo, de paredes horadadas a base de profundas incisiones, exigen para el trabajo en un material tan duro como el hormigón hidráulico, la colaboración de más de un individuo. Ya expuso Cressier, que el papel de los clérigos o de la iglesia directamente no debió de ser relevante, entre otras cosas por la mezcla de elementos paganos entre la gramática empleada (pentalfas, herraduras..), la imprecisión de las referencias cristianas y la ausencia de otros elementos litúrgicos importantes.

En nuestra opinión lo más probable, es que gran parte de lo que consideramos el primer nivel de graffiti, aquellos de contenido bélico, los ejecutaran soldados. Las razones deben ser puestas en relación con la gran exactitud de elementos esenciales de las armas y los jinetes, especialmente las guarniciones de los caballos, (sillas, gualdrapas, riendas), algo propio de personas que han desempeñado el oficio militar durante mucho tiempo, el necesario para familiarizarse con tantos detalles; aunque aparentemente la perspectiva de algunos objetos como la ballesta nos parezcan un error técnico.

Es evidente que otras partes se deben a simples paseantes o viajeros, los mismos que inconscientemente han incorporado a su bagaje cultural una simbología observada en otros lugares de la geografía peninsular y que sin pretenderlo se convierten en los transmisores de la misma, trasladándola a edificios religiosos o civiles, castillos, torres o aljibes, con los que hoy podemos compararlos.

Visto desde una perspectiva global, el castillo de Monsalud y los conjuntos que encierra, son auténticamente modélicos, en el sentido de que la gama de símbolos que pueblan las paredes de sus muros, forman parte de un lenguaje colectivo y no intelectualizado de grupos sociales poco conocidos, en el que resulta tremendamente significativo que a pesar de la espontaneidad, el hecho de que el conjunto de figuras siga un patrón y se repitan por toda la geo- grafía peninsular, combinando -antropomorfos, zoomorfos, inscripciones y figuras geométricas-, en tan alto porcentaje, que resulta suficientemente sospechosos como para considerar que existe un lenguaje común, permitiéndonos albergar la esperanza de que pueden ser comprendidos.

Explicar el fenómeno, solo tiene cabida en una época en la que la expansión de los estilos arquitectónicos europeos, el continuo errar de cuadrillas de canteros, soldados, comerciantes, miembros de órdenes militares y religiosas, han convertido Europa en un solar común por encima de las fronteras de los reinos y estados existentes.

Nosotros hemos tratado de separar cada uno de los componentes a fin de vislumbrar en primer lugar los posibles niveles acumulados en sus paredes y en segundo lugar aislar de sus características particulares todos los detalles posibles que nos aproximen a los tiempos de realización y a su significado. Tal vez nos hallamos quedado en lo simple, a sabiendas que las motivaciones son muchos más complejas y que a veces el dibujo, y más el de graffiti no parten solo de un acto consciente, sino que a veces se convierte en algo mecánico, al interactuar un exhibicionismo reprimido o impulsos del subconsciente, lo que Barrera y otros (BARRERA et alh, 1999: 56; SOLO DE ZALDIVAR, 1991: 12) han llamado el dibujo automático.

Separando en lo posible los temas principales, nos encontramos con dos programas diferentes pero no independientes, uno de tipo escenográfico, en el que se representa un posible Cuerpo de ejército distribuido con la intención de recordarnos quizá un acontecimiento histórico relacionado con un episodio de la reconquista en estas tierras, y otro de tipo religioso, que tiene como finalidad la purificación del espacio mediante la práctica de un ritual de imposición de cruces, a modo de exorcismo. En vista de ello, al menos al primero habría que clasificarlo dentro de los paneles de tipo descriptivo conmemorativo, mientras que el segundo se incorpora como complemento para explicar a modo de subtítulos, quiénes son los protagonistas, cual es la fe que les ilumina y de 
paso servir de contestación a una costumbre arraigada en el Islam, donde los graffiti con textos de carácter religioso, eran algo más que un acto piadoso y perseguían la conversión de quién los contemplaba (BARCELÓ, 1977: 133).

En torno a esta cuestión nos vamos a encontrar numerosos ejemplos de un extremo a otro de la Península, demostrando que este no es un fenómeno local, sino de largo alcance. Casos como el de la piedra de Savassona en la comarca de Vic en Cataluña con representaciones de cruces, herraduras, estrellas y otros símbolos, incluida una figura humana, son puestas en relación por su investigadora, (CASANOVAS, 1982: 459) con el esfuerzo de la iglesia por superponer su doctrina a las costumbres de las poblaciones ya existentes, uno más de los muchos casos conocidos en Galicia, en Castilla y en la propia Extremadura.

Se trata más bien, en nuestra modesta opinión, de la obra de un testigo o testigos, que han dejado constancia de un acontecimiento a través de un relato combinado con una expresión de las supersticiones, que en el acervo popular tienen tan hondo calado que sobreviven junto al cristianismo, aunque el espíritu de la contrarreforma barrerá más tarde una buena cantidad de ellas, Esa es quizá la razón por la cual en los siglos XVII y XVIII desvirtuados y despojados de su significado original, -cruces, estrellas, medias lunas, gatos y otros signos- aparecerán en las leyendas y libros de tesoros, transformados en "señales de yacimientos metálicos u otros objetos preciosos". A ellos se referirá con ironía el erudito cacereño Publio Hurtado, al hablar precisamente de la seriedad con que se tomaban la búsqueda de riquezas ocultas en los siglos antes mencionados (HURTADO, 1989: 144), dejando de paso constancia del conocimiento y abundancia que había de estas señales, parcialmente inventariadas en uno de nuestras trabajos más recientes (GONZÁLEZ, 2000).

Su realización a la vista de lo que hemos comentado no obedece a un tiempo preciso, es un panel vivo, en el que las fechas de los motivos se superponen unas a otras desde el abandono mismo del castillo, remontándose los primeros esquemas probablemente a los principios del siglo XIV, fecha que asignamos principalmente a los temas de jinetes y a los primeros cruciformes, durante el XVI se añaden detalles aislados, la ballesta, pentalfas, herraduras, nuevos personajes, cruces con bulbo y entre el $X V I I$ y XVIII, de nuevo soldados con gorros y sables, nuevos símbolos, cruces, alfabetiformes y ya en el $X I X$ y $X X$, cruces, fechas iniciales de nombres, etc.

Ya hemos adelantado que el estudio de los grabados sobre paredes de edificios de época histórica pueden ser de gran utilidad para corregir las dataciones de aquellos conjuntos que abarcando la misma panoplia de símbolos, al hallarse en cuevas, abrigos o rocas al aire libre, se valoran automáticamente como producciones prehistóricas, algo muy común incluso en el tiempo presente a pesar de las continuas llamadas a la reflexión para avanzar en la clarificación del problema. Igualmente pueden servir para que otros que han sido realizados en tiempos históricos, puedan ser encasillados dentro de unos márgenes de tiempo más coherentes, aludiendo con esto a sitios como el aljibe de Daimuz (CARA Y RODRÍGUEZ, 1989: 48), plagado de cruces, herraduras, emparrillados, escaleriformes, etc., que los autores atribuyeron erróneamente a cristianos de la primera mitad del siglo VI o la Cueva Perica, de Alfacar (Granada), con cruciformes datados como prehistóricos (ZAPATA, et alii, 1995), cuando se han hemos visto por centenares en edificios y rocas de época histórica.

Aunque el valor histórico de los graffiti, y más extensamente, de todos los signos lapidarios sean unánimemente reconocidos, su estudio sistemático es aún marginal y se encuentra más desarrollado en las zonas orientales de España, principalmente Levante e Islas Baleares. Entre todas las comunidades que componen el área descrita, Malloca ha destacado por sus descubrimientos y publicaciones sobre graffiti históricos, quizá porque sus soportes han podido hace tiempo poner en duda las tesis prehistoricistas y sacudirse el sambenito que arrastran los estudios del Arte Rupestre; ello no quiere decir sin embargo que las producciones de estas zonas sean más abundantes, sino que se ha puesto mayor cuidado en el estudio y 
conservación de este patrimonio. De ahí que constituya un modelo a imitar y que igual que en esa comunidad se ha llamado la atención sobre la relevancia de estas manifestaciones como documentos históricos y la necesidad de conservación, en el marco de las restauraciones de que son objeto los edificios antiguos, no estaría de más solicitar desde aquí, que en futuros capítulos de inventarios de la comunidad extremeña, se incluyan los hallazgos graffíticos y gliptográficos como elementos del patrimonio cultural, pues estos dibujos que han sido vistos con frecuencia como un "testimonio del vandalismo o trazos espontáneos de poco valor", como bien ha comentado E. González (1990: 272) son la imagen viva de una época, sin olvidar los detalles gráficos que pueden aportar a la arqueología.

\section{BIBLIOGRAFÍA}

ÁlVARO BOBADILLA, E. (1974): "Pinturas rupestres del Cerro de La Cabra, en Ojos Albos (Ávila)", Boletín Informativo de la Asociación Española de Amigos de la Arqueología. 2. Madrid, pp. 14-19.

ANATI. E. (1966): "El Arte Rupestre Galaico-Portugués", Simposio de Arte Rupestre. Barcelona, pp. 195-256.

BALESTEROS, C. y RIBEIRO, M. (1999): "Marcas de cristianizacáo nos núcleos urbanos antigos de Alpalháo e Valencia de Alcántara (Cáceres)". Ibn-Maruán. 9-10. Marvao, pp. 39|-4I6.

BARCELÓ, C. (1977): "Graffti árabes: un intento de clasificación", Los Muros tienen la palabra. Materiales para una historia de los graffiti. Valencia, pp. 121-147.

BARRERA, J. ।.; CRESSIER, P.y MOLINA, J.A. ( I 999):" "Garabatos de alarifes: los graffiti de las galerías de Desagüe de Madinat al-Zahra", Cuadernos de Madinat al Zahra. vol. 4. Córdoba, pp. 38-8I.

BARROCA, M. J. (2000).: "Dossier iconográfico", Era Guerrera. Armamento medieval no espaco portugués. Palmela, pp. 78-1 10.

BAllANA, A (1999): "-Al-Djubb-: "Le stockage de l'eau dans les édifices castraux et les habitats d'Al-Andalus", Archéologie des espaces agraires méditerranéens au Moyen ge, Castrumm. 5. Madrid,pp.37I-375.

BERROCAL RANGEL, J. L. (1993): Los pueblos célticos del suroeste de la Península, Complutum, Extra. 2. Madrid, p. 323.

BELTRÁN MARTÍNEZ, A. (1989): Ensayo sobre el origen y significación del Arte Prehistórico. Zaragoza.
BERTRÁN I ROIGÉ, P. (1986): "Dos models d 'Hábitat fortificat: Sant Llorenc del Monsec i Oroners (La Noguera)", Setmana d'Arqueología Medieval. Lleida, pp. 105-128.

BRUHN, A. (1988): "Las armas en la historia de la reconquista", Actas del Simposio Internacional sobre -Armas en la Historia-. Gladius. n. especial. Jaraiz de la Vera, pp. 31-I0 I.

BUENO, P. y BALBIN, R. de (1997): "Arte megalítico en sepulcros de falsa cúpula. A propósito del monumento de Granja del Toniñuelo (Badajoz)", Brigantium. I0. La Coruña, p. $9|-| 2 \mid$

CARA BARRIONUEVO, L. y RODRÍGUEZ LÓPEZ, J. M. (1989): "El pastoralismo en Al-Andalus. Aproximación arqueológica en el sureste peninsular", Revista de Arqueología. 96. Madrid, pp. 47-49.

CARBONELL I ESTELLER, E. (1981): "Els grafits de Castellfolit de Riubregós. Primeres aportacions", Quaderns d'Estudis Medievals. 5. Barcelona, pp. 278-310.

CASSANOVAS I ROMEU, Ma. A. (1982): "Savassona. Notes per al plantejament de la problemática deis gravats rupestres catalans", Quaderns D'Estudis Medievals. 8,Vol. I. Barcelona, pp. 45।-46|.

COSTAS GOBERNA, F. J. y PEREIRA GARCÍA, E. (1998): "Los grabados rupestres en épocas históricas", Reflexiones sobre el arte rupestre prehistórico de Galicia. Vigo, pp. 129-172.

CRESSIER, P. (1986):" Graffitis cristianos sobre monumentos musulmanes de la Andalucía oriental: una forma de exorcismo". Actas del I Congreso de Arqueología Medieval Española. Zaragoza, pp. 273-29l.

DHINA ALGER, A. (1984): Les états de l'occident musulman aux XIII, $X I V$ et $X V^{e}$ siecles: institutions gouvemementales et administratives. Alger.

FERNÁNDEZ, C.; FERNÁNDEZ SANDINO, J.; SAIZ, L. Y MÁRQUEZ, Ma.J. (1987): Informe preliminar de los grabados bajo medievales del castillo de Jubera (La Rioja) y su entorno histórico-arqueológico. Logroño.

FERRO COUSELO, J. (1952): Los petroglifos de término y las insculturas de Galicia. Orense.

FLORIANO, A. C. (1934): Documentación histórica del Archivo Municipal de Cáceres (I 227-1 504). Cáceres,

FORTEA, J. (1970-7| ): "Grabados rupestres esquemáticos en la provincia de Jaén", Zephyrvs. XXI-XXII. Salamanca, pp.139-159.

GISBERT; J.A. (1984):"'Los graffiti medievales del Castell de Denia", Exposición monográfica, Julio-Sept de 1984. Maison de L'Orient Méditerranéen. Casa de Velázquez. LyonMadrid.

GÓMEZ BARRERA, J. A. (1992): Grabados rupestres postpaleolíticos del Alto Duero. Soria.

GÓMEZ BARRERA, J. A. (1993): Arte Rupestre Prehistórico en la Meseta Castellano-Leonesa. Valladolid.

GONZÁLEZ CORDERO, A.(2000): Los grabados postpaleolíticos altoextremeños. Su inserción en un marco cronológico. Trabajo de investigación inédito UEX. Cáceres. 
GONZÁLEZ GONZALO E. (1988):"los graffiti de la Lonja de Palma de Mallorca", Actes du Vlle colloque international de glyptographie de Rocherfort-sur-Mer. tomo I, (38 juillet 1990), Rochefort-sur-Mer, pp. I23- 132.

GONZÁLEZ GONZALO E. (1990): "Los graffiti históricos y las pinturas murales populares. Primer paso para su protección y salvaguarda en el ámbito del patrimonio cultural", BSAL. 46. pp.27I-274.

GONZÁLEZ, A. y QUIJADA, D. (199|): Los orígenes del Campo Arañuelo y la jara cacereña y su integración en la Prehistoria regional. Navalmoral de la Mata (Cáceres).

GUICHARD, P. y MISCHIN, D. (en prensa): "La société du Garb al-Andalus et les premiers husilin", Actes du colloque de Palmela 200 I. Palmela.

HURTADO, P. (1989): Supersticiones extremeñas. Cáceres. Reed. de 1902.

IBN AL-ATIR -s.XIII- (190I): Annales du Maghreb et de l'Espagne, (trad. Fagnan). Alger. p. 205

IBN HAYYAN -s. XI- (Muqtabis III, 1973):Al-Muqtabas Min anba: ahlal-Andalus. ed. M. A. Makki, Beirut. pp. 347-355

IBN AL-'IDARI -s. XIII-XIV- (Bayán II, I90 I - 1904): Histoire de l'Afriqueet de l'Espagne intitulée al-bayano I-Mogrib, (trad. E. Fagnan), 2 vol. Argel. pp. 100- 103.

IZQUIERDO BENITO, R. (1994): Ciudad hispanomusulmana de -Vascos-, Navalmoralejo (Toledo). Campañas 1983-1988. Toledo-Madrid.

LÓPEZ CANO, E. (199|): Alburquerque, Villa y ducado. Cuadernos Populares. 44. Mérida.

MANZANO, E. (199 I ): La frontera de al-Andalus en época de los omeyas. Madrid.

MARTÍNEZ LÓPEZ, J. (1950): "Petroglifos de Breixa, comarca de Lalín (Pontevedra)", Ampurias. XIX-XX. Barcelona, pp. 266-274.

MAYA, J. L. (1977): "La Peña del Guisaero, estaciones con grabados esquemáticos en la provincia de Albacete", XIV. Congreso Nacional de Arqueología. Zaragoza, pp. 5 I 5-524.

MARQUÉS DE MONSALUD (190I): "Citanias extremeñas", Revista de Extremadura. III. Cáceres, pp. 6- 13.

MARTÍNEZ DE ESPINAR, R. (1644): Arte de Ballestería y Montería. Madrid.

MONTOLLA RAMÍREZ, Ma. I.(|99|): El libro de la Montería de Alfonso XI. Ed. crítica Universidad de Granada. Granada

MORA FIGUEROA, L. de (1984): "El Castillo de Nogales ( 1458 - | 464). Provincia de Badajoz", Estudios de Historia y de Arqueología medievales. I I I-IV. Cádiz, pp.2 I 5-246.
MURILLO MARISCAL, M. (1977): Historia de unos hallazgos arqueológicos y algo sobre los Congresos de Estudios Extremeños. Badajoz.

NAVARRO POVEDA, C. (1993): Graffiti y signos lapidarios del castillo de Mola (Novelda) y del castillo de Petrer. Alicante.

VIÑAS, R. y SARRIÁ, E., "Los grabados medievales del Raco Molero (Ares del Maestre, Castellón)", Cuadernos de Prehistoria y Arqueología Castellonenses. 8. Castellón de la Plana, pp.287-298.

ORTEGO FRIAS, T (1974): "Nueva estación de arte rupestre en el término de Oteruelos (Soria)", X Congreso Nacional de Arqueología. Soria, pp. 205-215.

RODRÍGUEZ DÍAZ, A. (1989): "La segunda edad del hierro en la Baja Extremadura: problemáticas y perspectivas en torno al poblamiento", Saguntum, 22. Valencia, pp. |65-23|.

SANTOS JUNIOR, J. R. y AZEVEDO, R. (1960-61): "Gravuras rupestres, ensaio interpretativo". Trabalhos de Antropología e Etnología. XVIII, ( I-2). Porto, pp. 43-62.

SERRA I BARCELÓ, J. (1986): "Graffiti de presos y asilados. El caso de Mallorca", Actas del V Coloquio Internacional de Gliptograffa. Pontevedra, pp. 9I5-934.

SEVILLANO SAN JOSÉ, Ma. C. (199|): Grabados rupestres en la comarca de Las Hurdes. Salamanca.

SIMONET, F. J. ( I 897-1903): Historia de los mozárabes de España. Madrid.

SOLER, A. (1990): Evolución del armamento medieval en el reino castellano-leonés y Al-Andalus (s. XII-XIV). Vol. I. Tesis Doctoral. Madrid.

SOLER, A. (2000): "El armamento medieval islámico en la Península Ibérica", Era Guerrera. Armamento medieval no espaw portugués. Palmela, pp. 15-36.

SOLO DE ZALDÍVARYÉBENES, P. (|99|):"Los cruciformes del cementerio de Maro, en Nerja (Málaga)", Jábega. 7I. Málaga, pp. 3-14.

TERRON ALBARRÁN, M. (199|): Extremadura Musulmana. Badajoz.

VALENCIA DE DON JUAN. Conde Viudo de (1898): Catálogo descriptivo de la Real Armería de Madrid. Madrid.

VELHO, M. (|98I): "Ibn Marwân (ibn al-Djilliki) e Sa'dûn Surunbâqui. A localizaço de Monsalude", Proceedings of the ninth Congress of the Union European d'Arabisants et d'Islamisants. Leiden, pp.270-287.

ZAPATA, A.;ANIBAL, C.y PACHÓN, J.A. (1995): "Hallazgos inéditos de Alfacar", Revista de Arqueología. 169. Madrid, pp. I0- I5. 


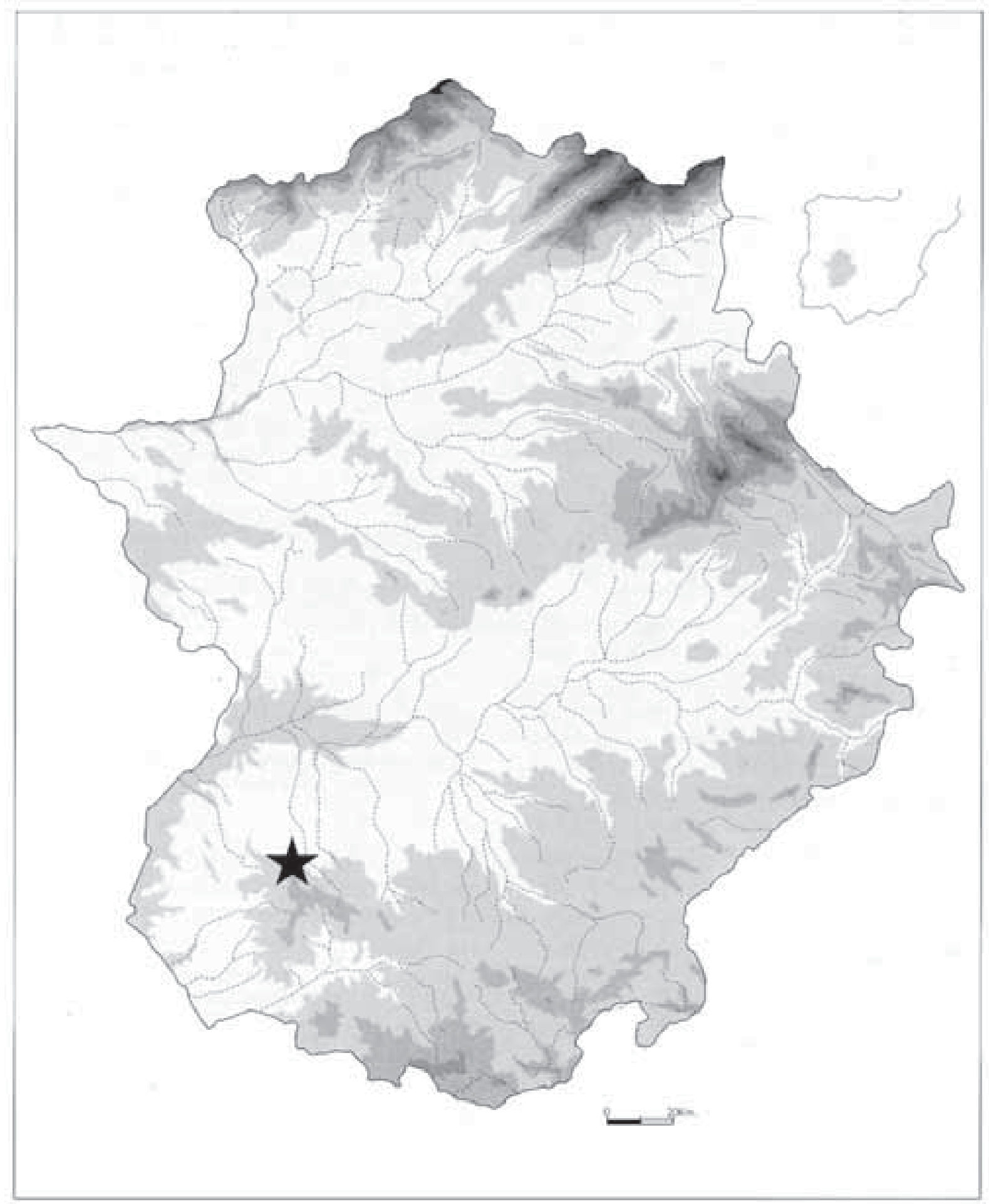

Figuro I. Localizooión del yocimiento de Monsolud (Nogaies, Badajoz). 


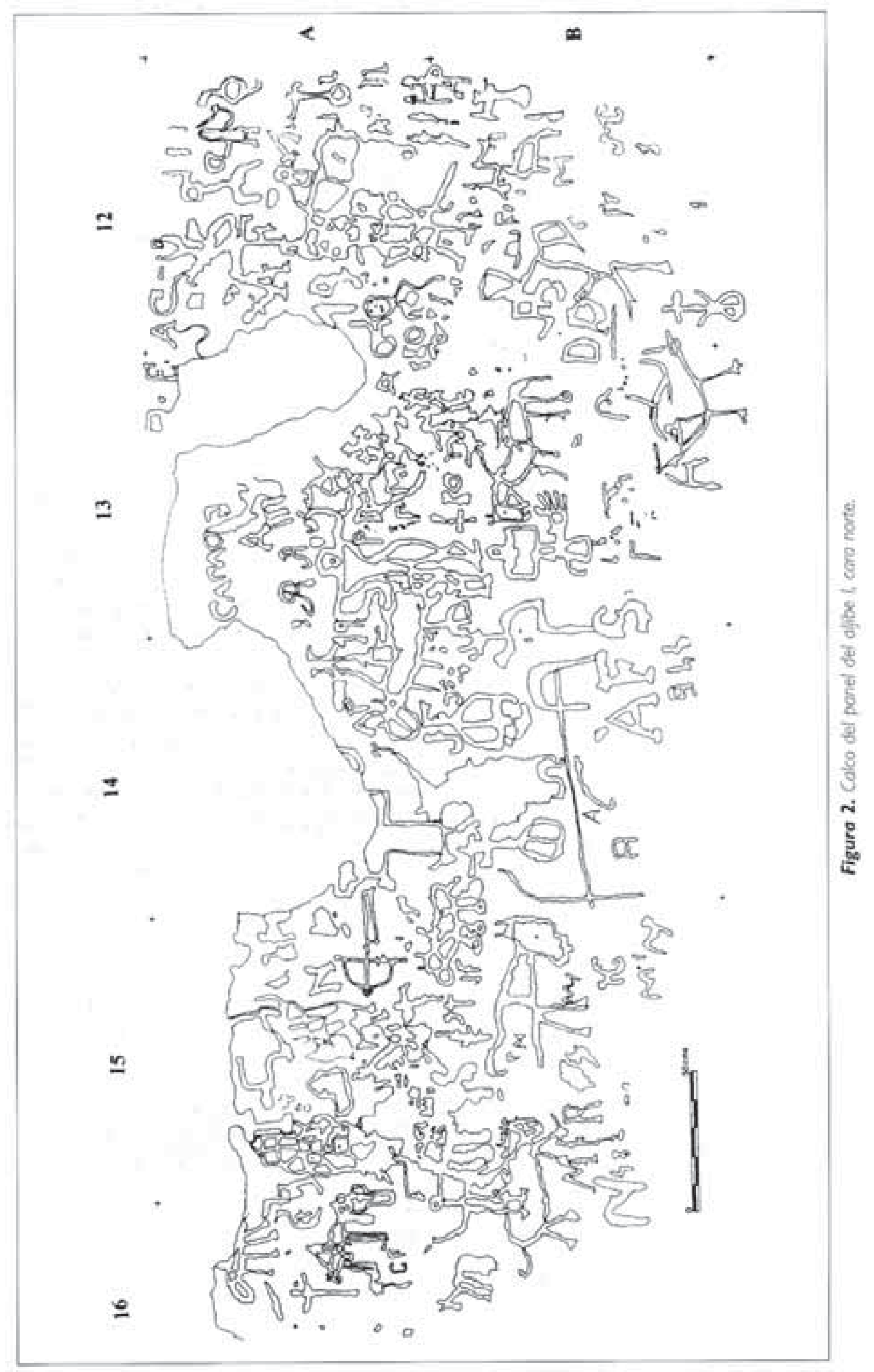




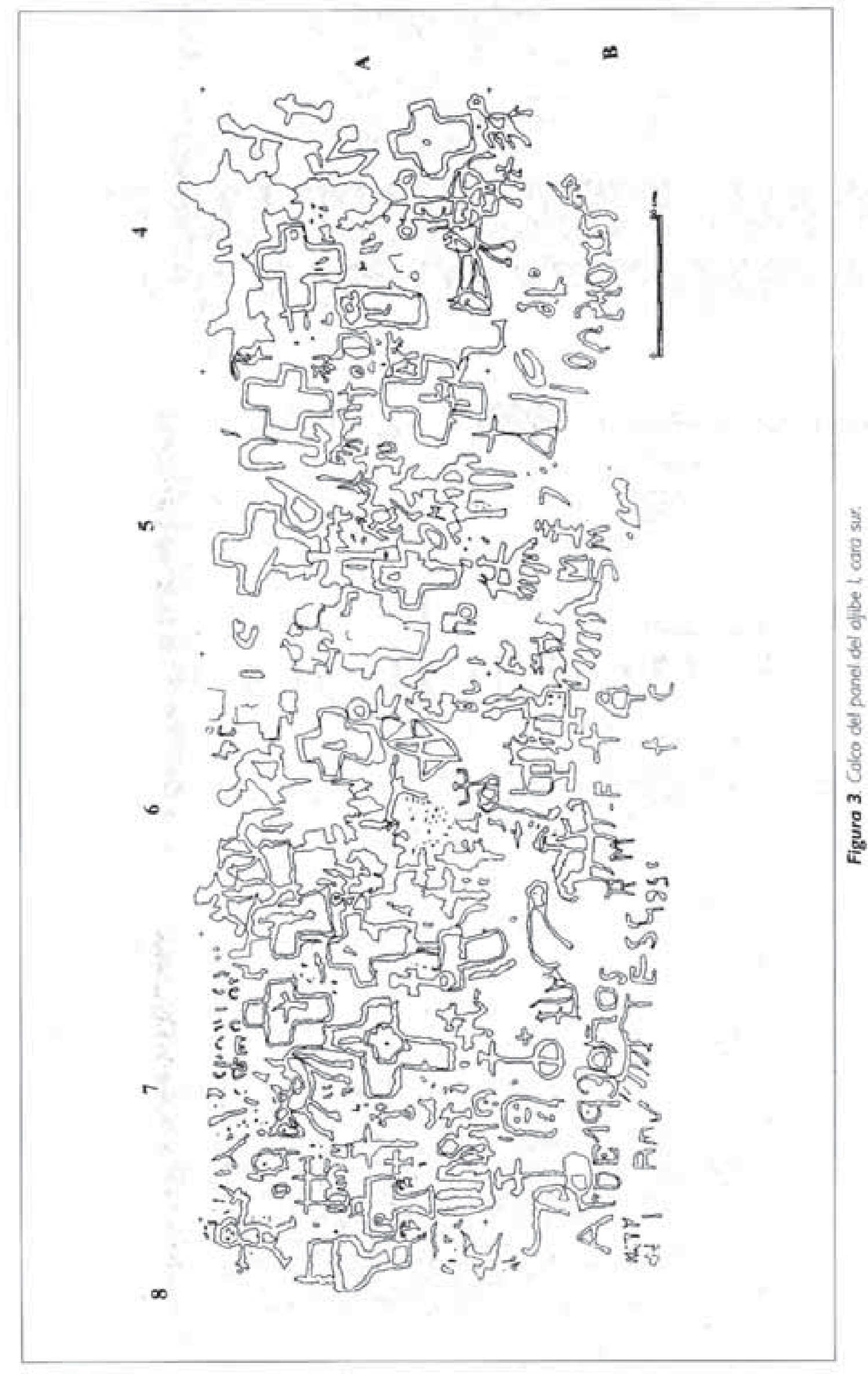




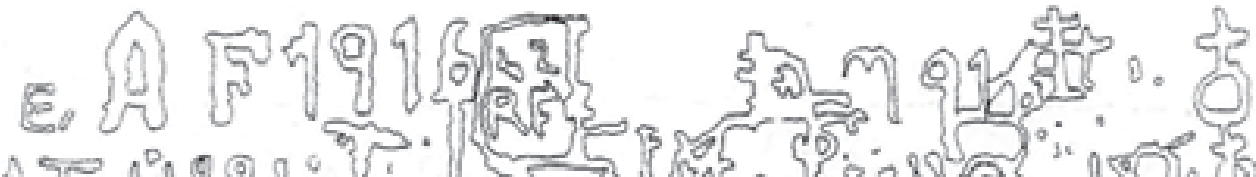

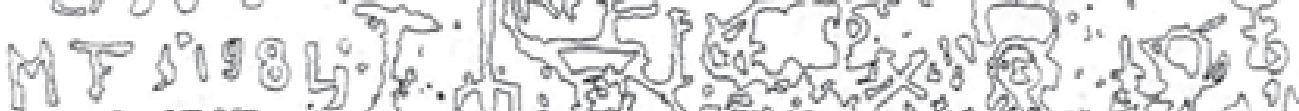
R०00.989:

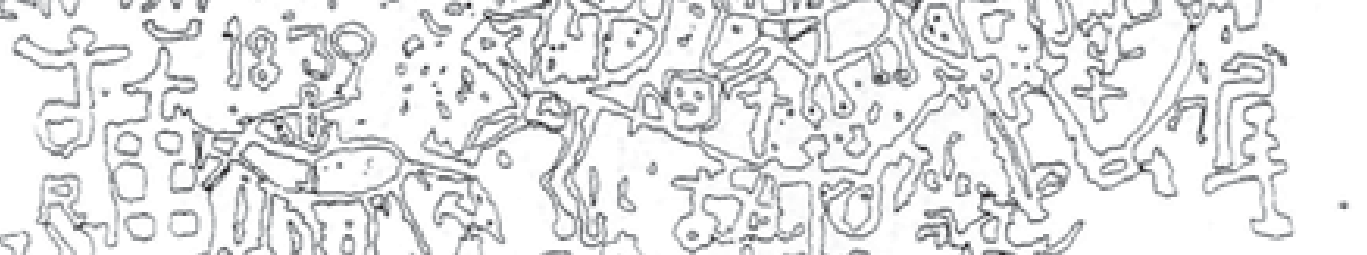

A

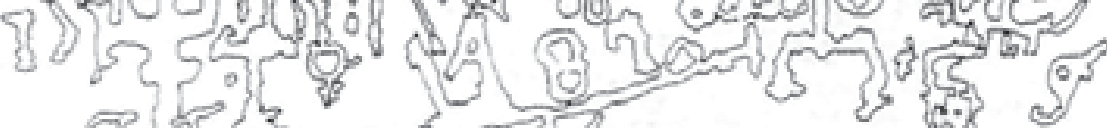

$$
\text { - M - M }
$$

11

10

9

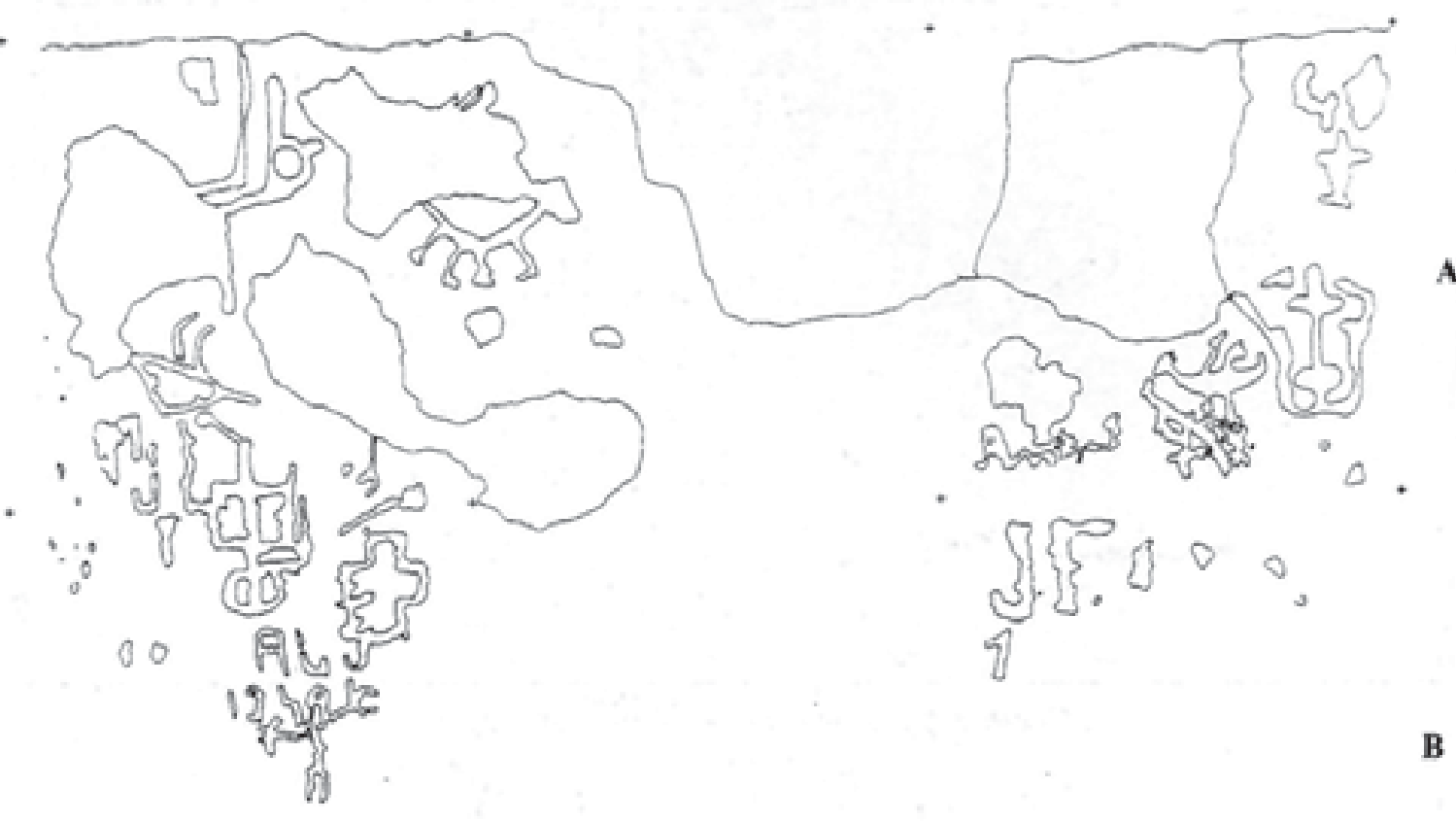

Figura 4. Calco del panel del aljibe I, caro este y oeste. 


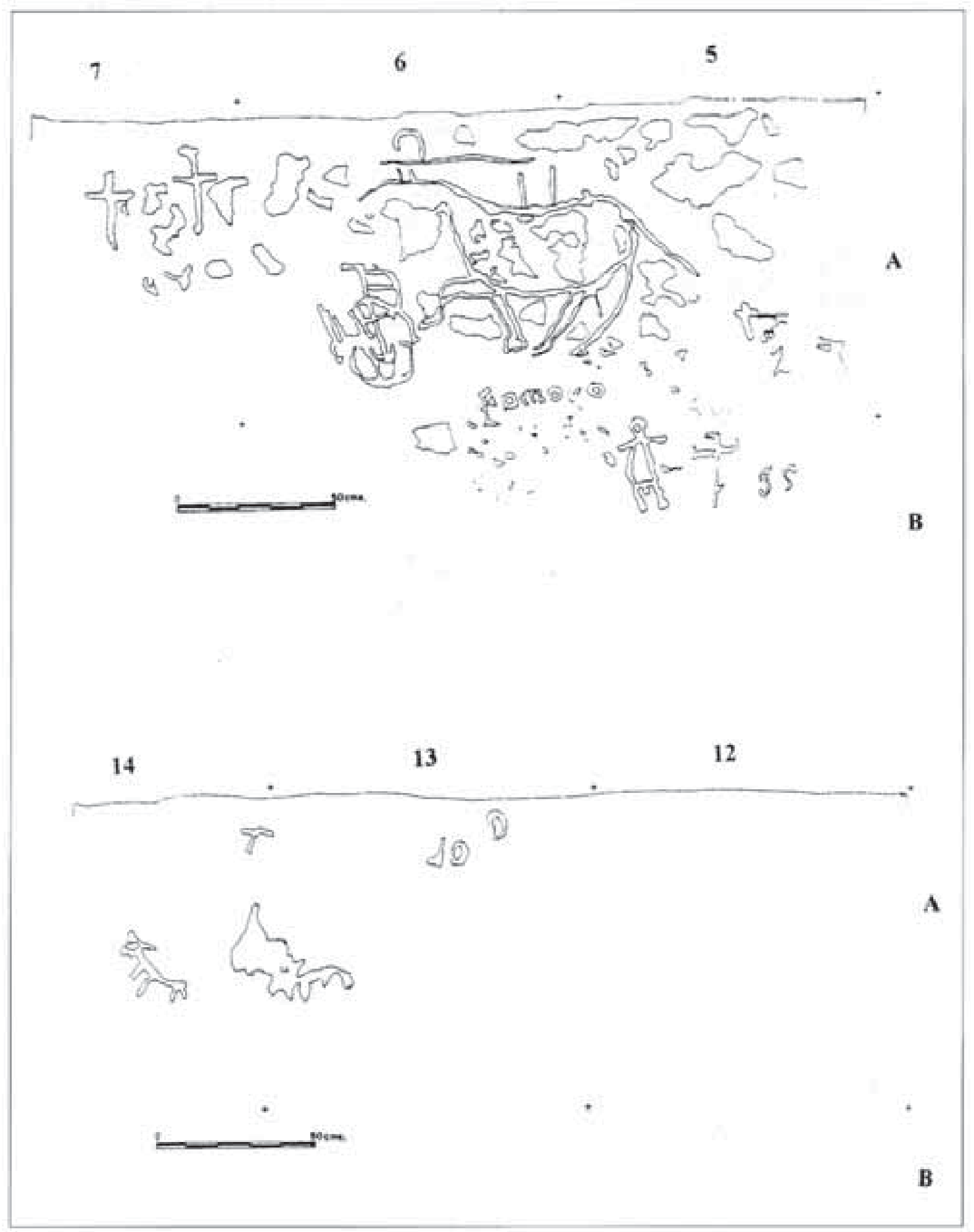

Figura 5. Calco del panel del afjibe Ili, cara norte y sur. 


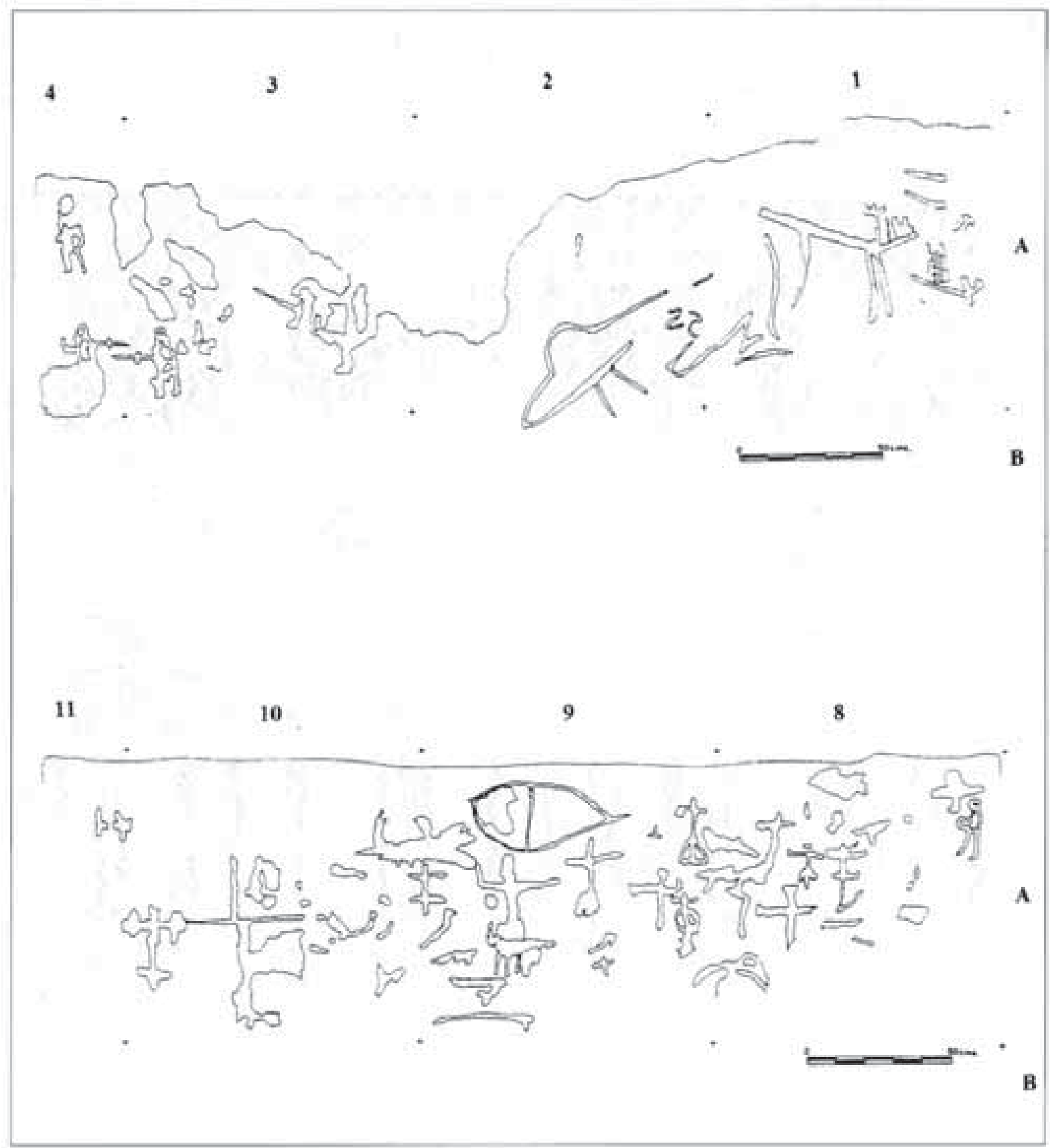

Figura 6. Calco del panel del ajibe Hil cara este y peste. 

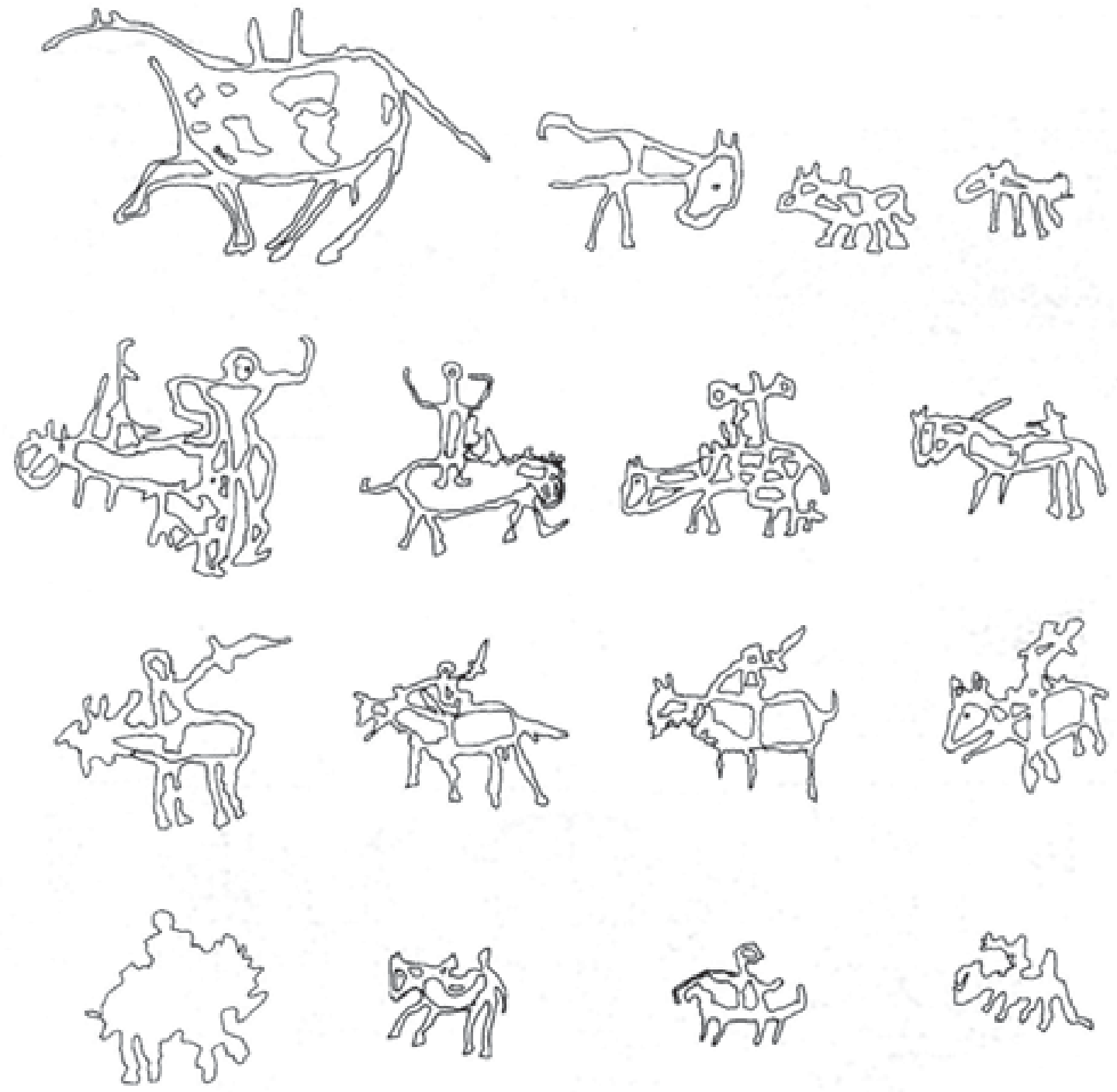

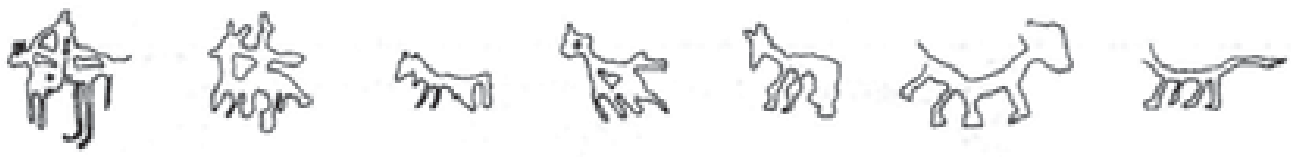

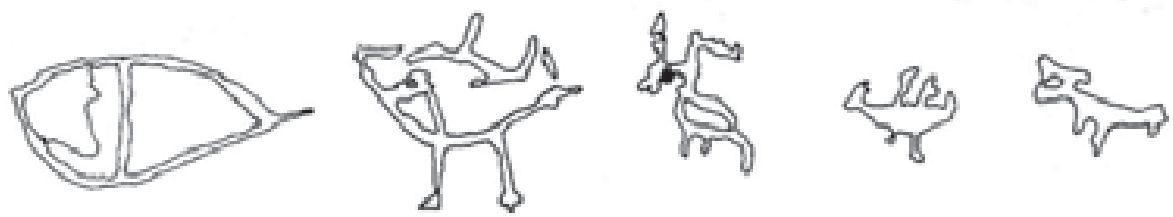

Figura 7. Tipología comparada de representaciones zoomórficos, con/sin antropomorfos. 


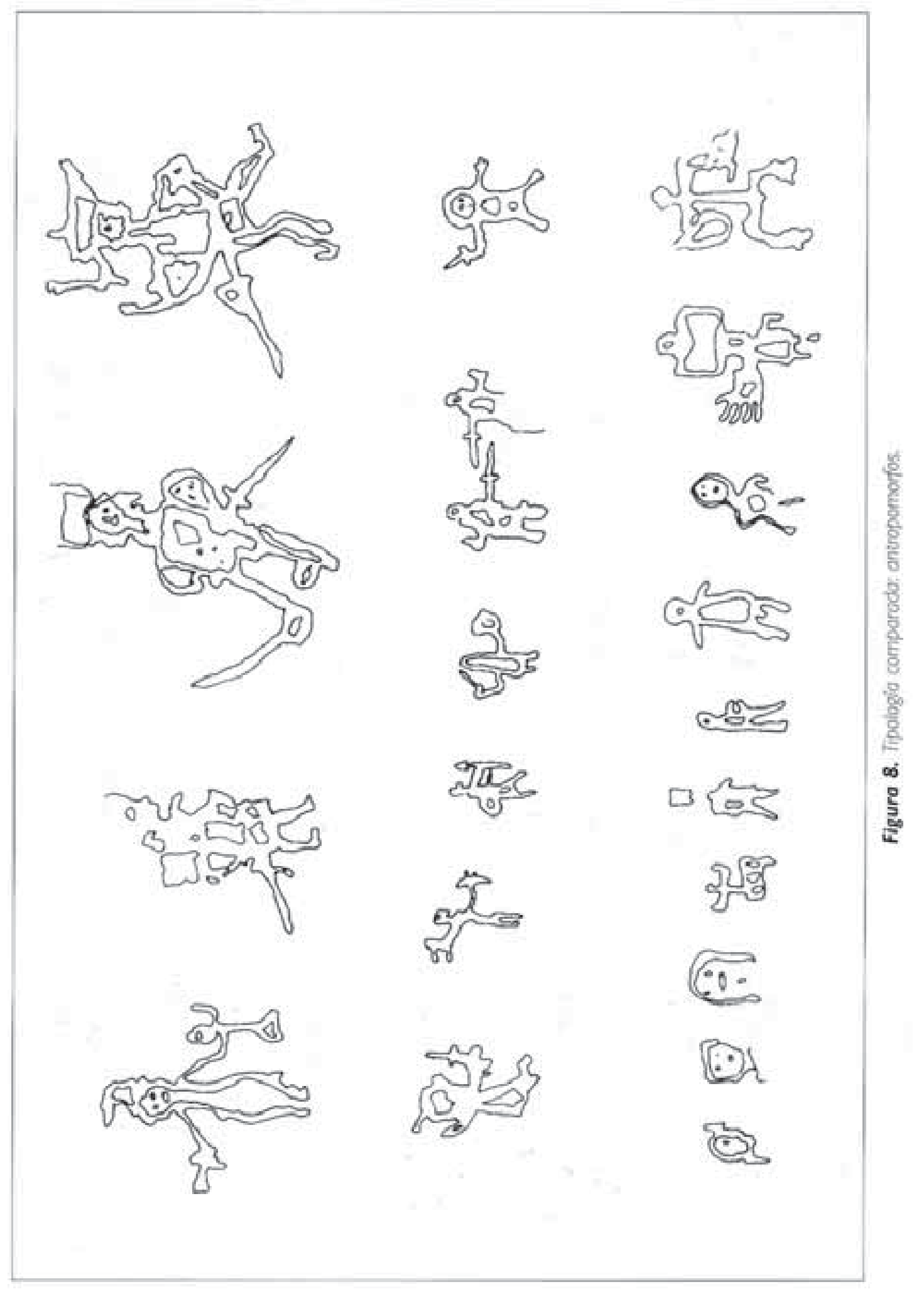




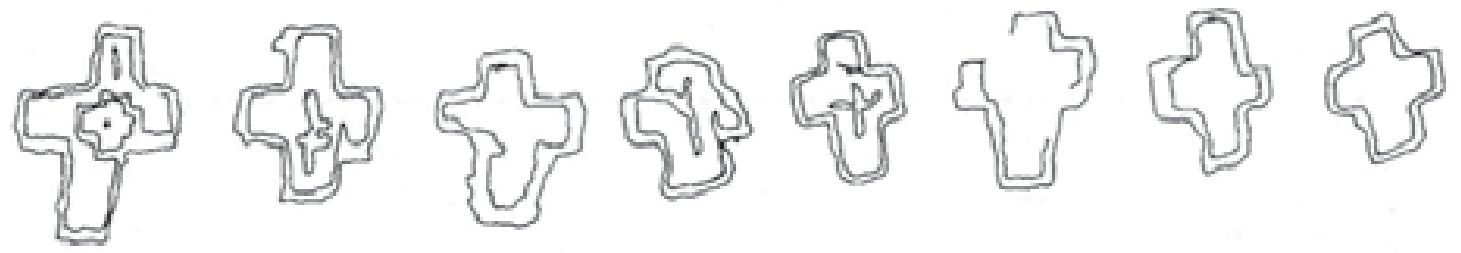

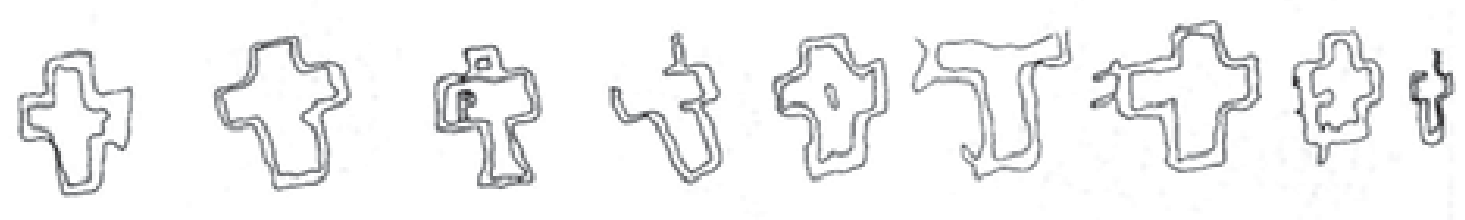

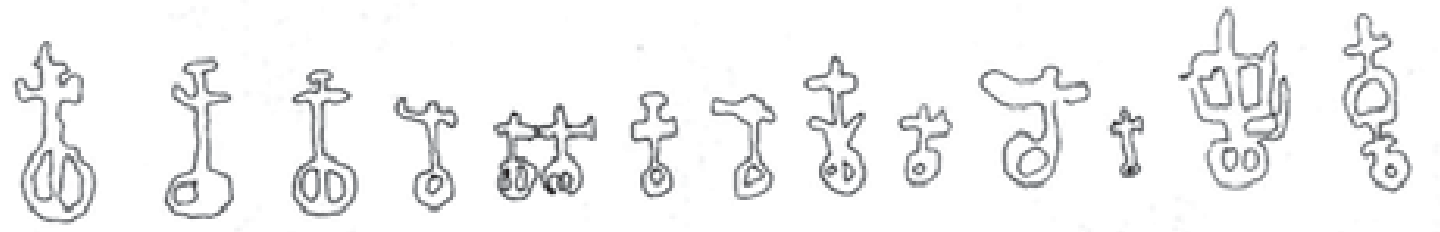

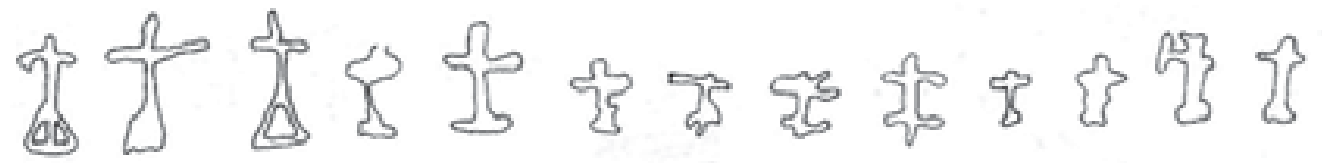

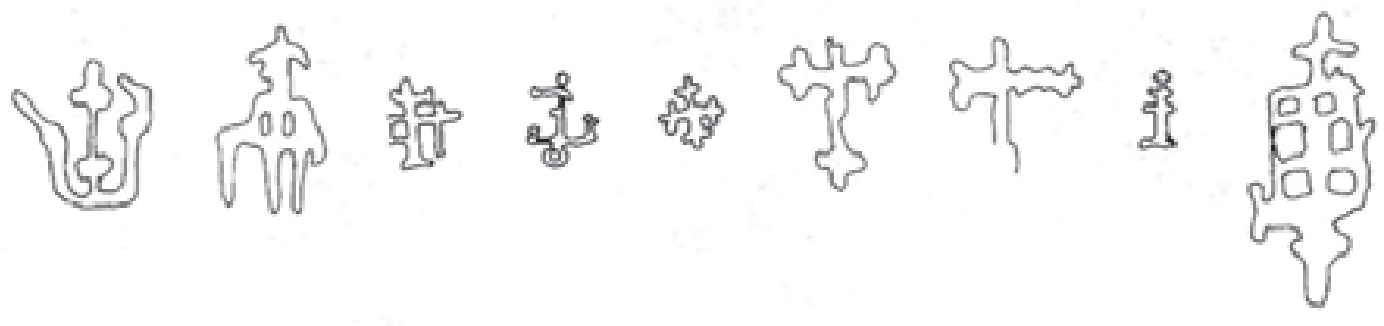

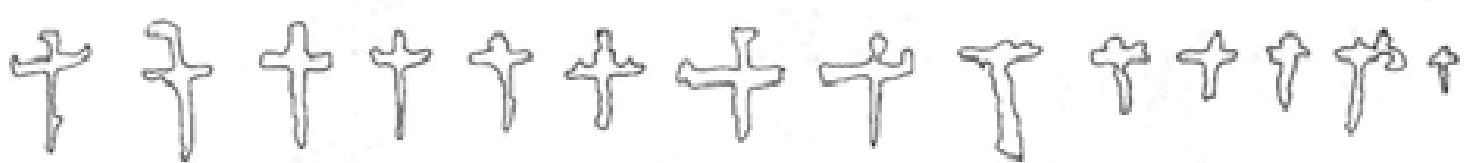

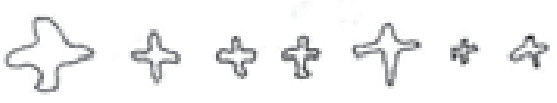

Figura 9. Tipología comparoda: cruciformes. 
M

बरु० ?

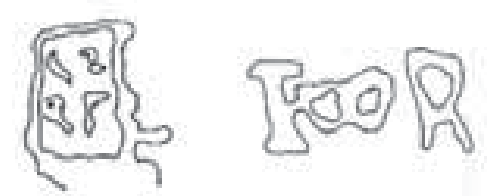

क्येग

बिद्व 且政

S[S. M M

8

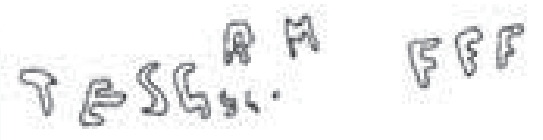

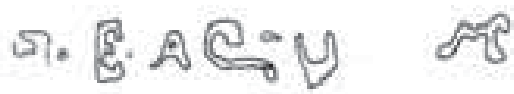

$\infty$

PQ

Fु

SAOROS $\triangle B$ कणी

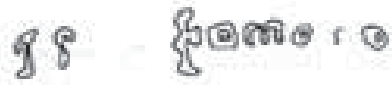

คื

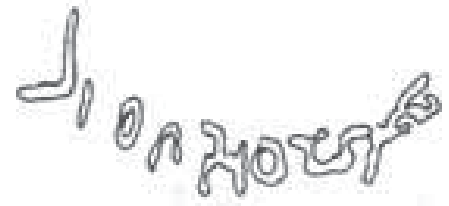

एकी ज9998

ๆ ใ?

$12068 \cdot 9987$

MP

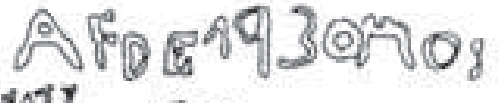

ใู ดูล

$983^{\circ}$

Figura 10. Tipología comparada; carocteres epignuficos: 


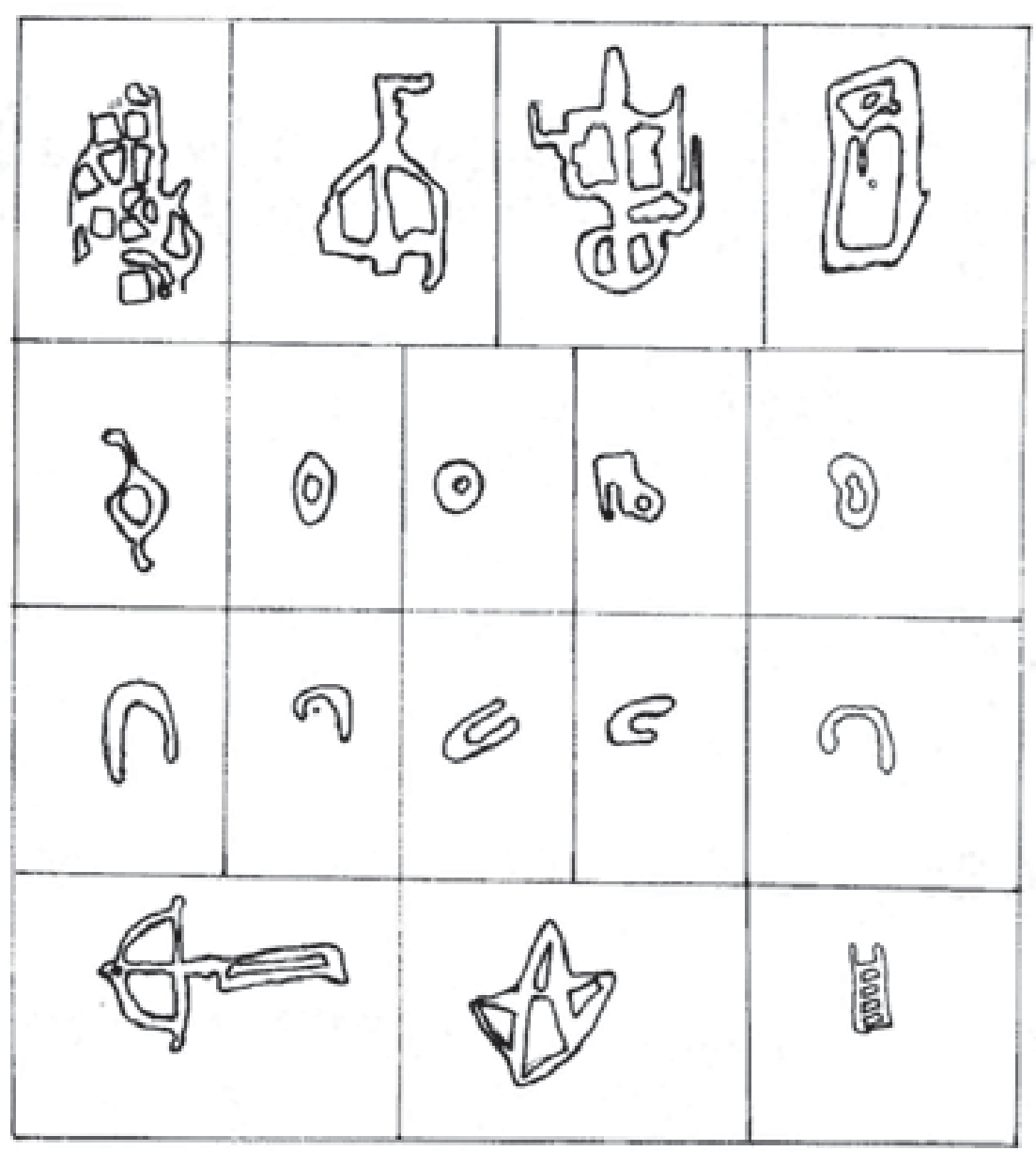

Figura II. Cuodro de elementos diverso: ammas, pentalfos, escoleriformes, herraduras, motivos circulares y motivos aplantillodos. 


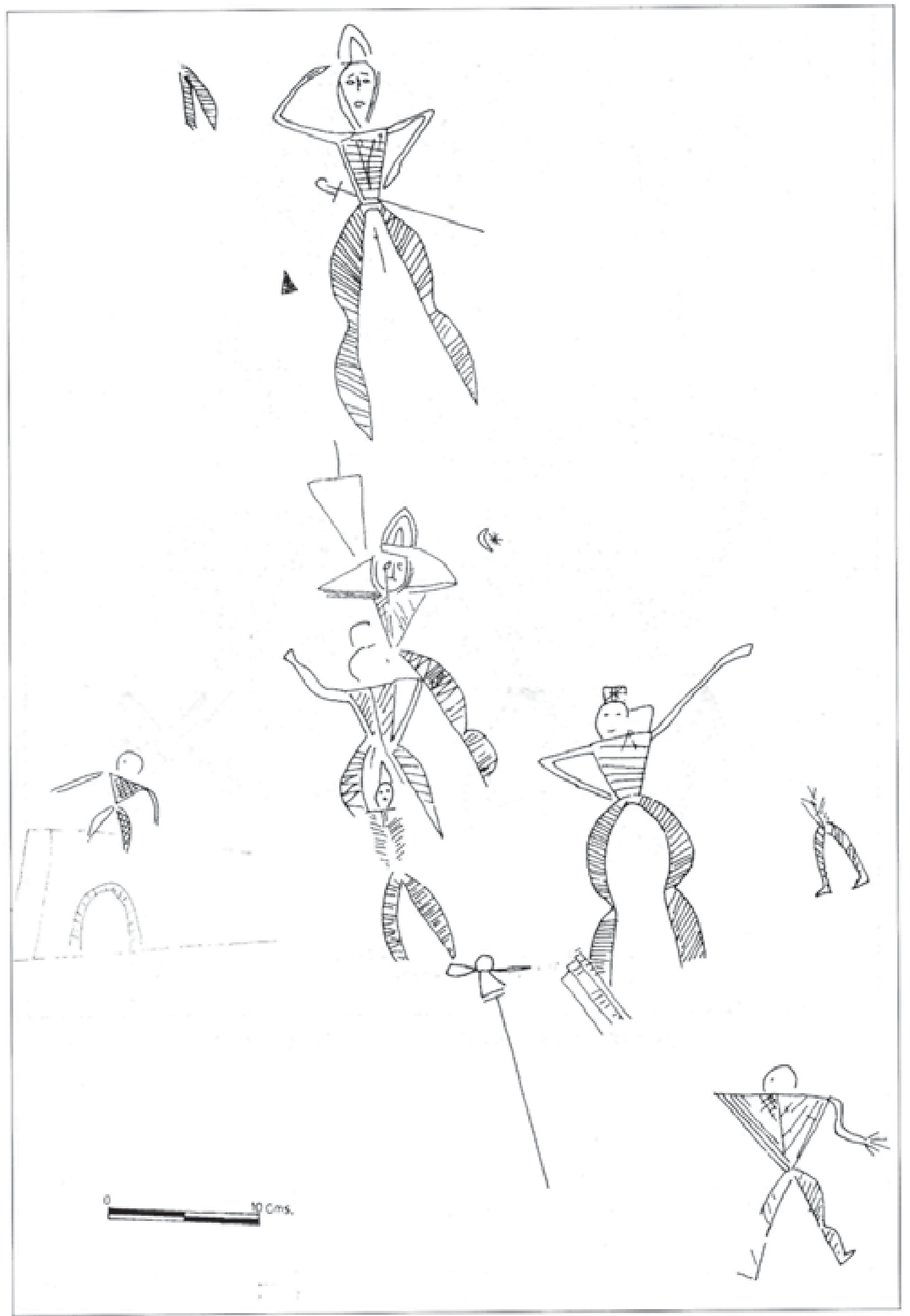

Figura 12. Grabados del Molino de la Ferreria (Navalililar de Ibor, Cóceres) 


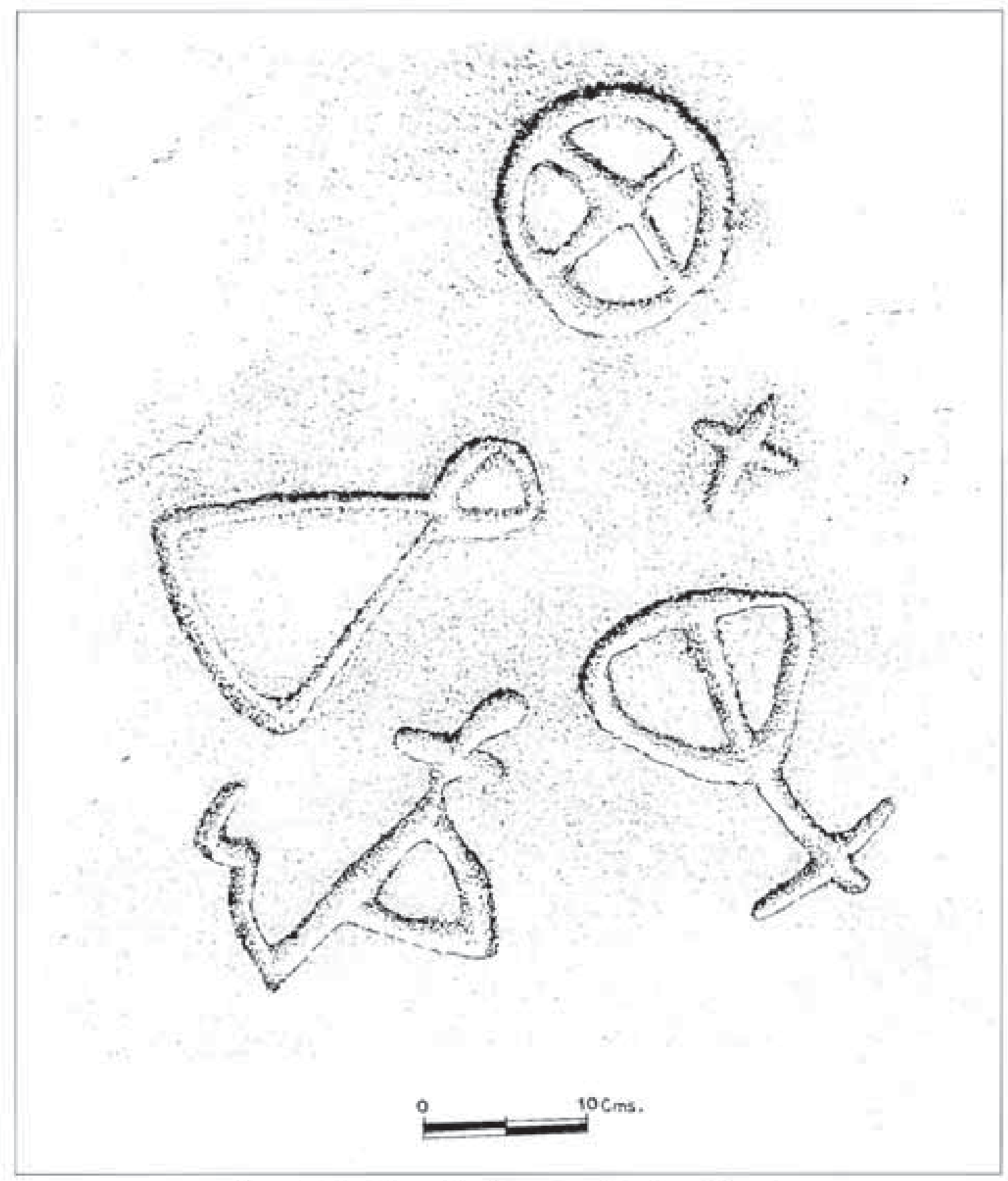

Figura 13 San juan el Alto (Santa Cruz de la Siema, Cóceres) 


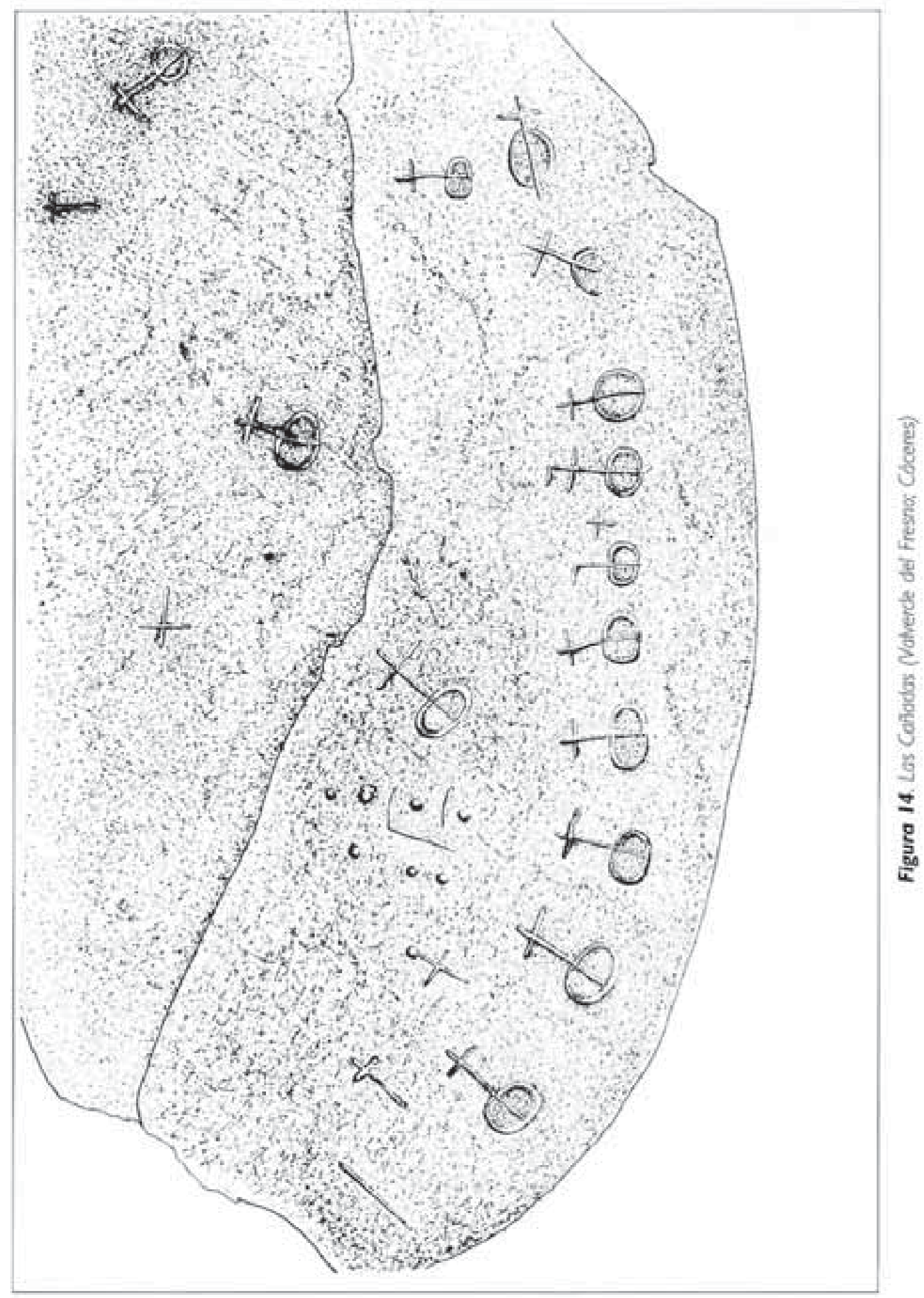




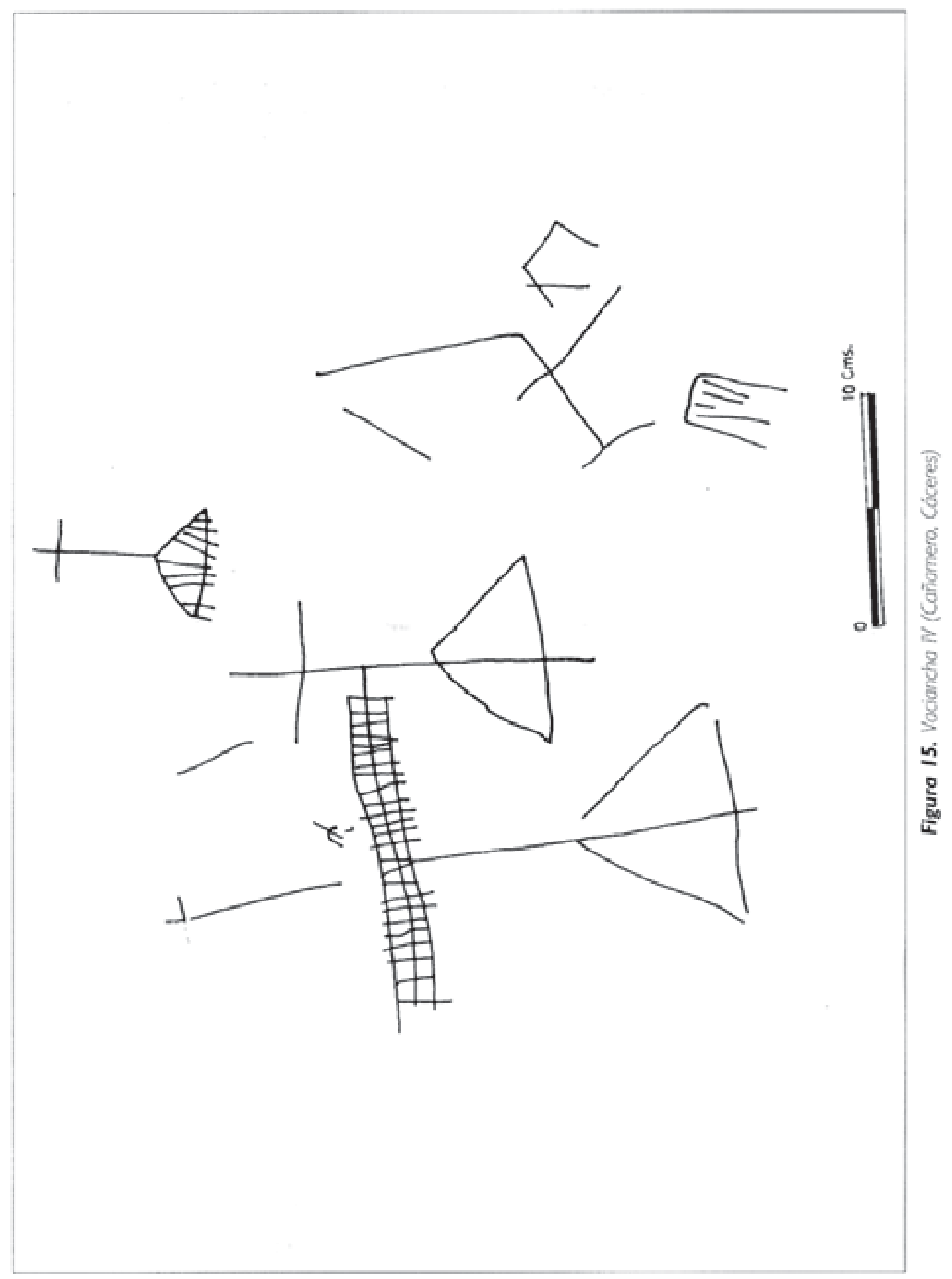




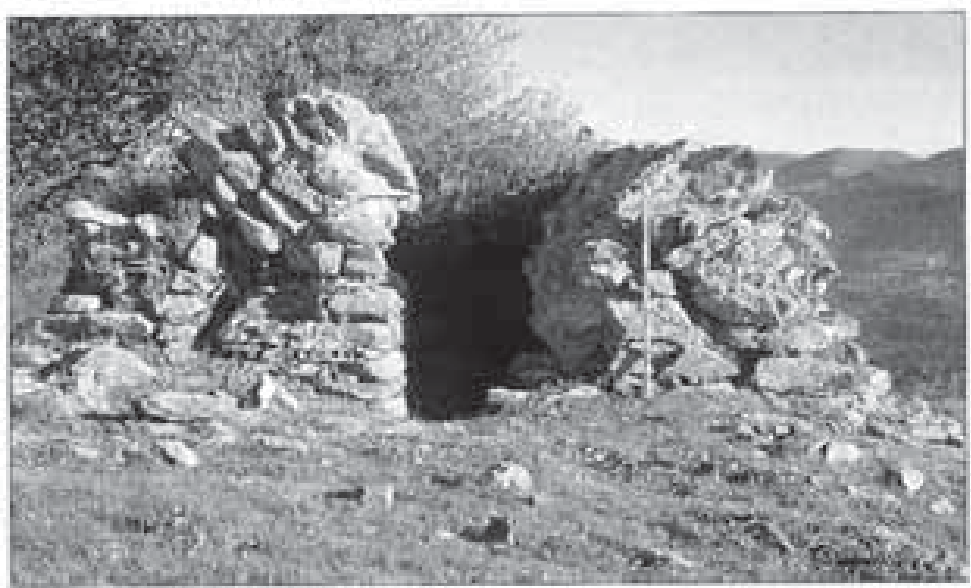

Lámina I Vista frontal dol qujibe 1.

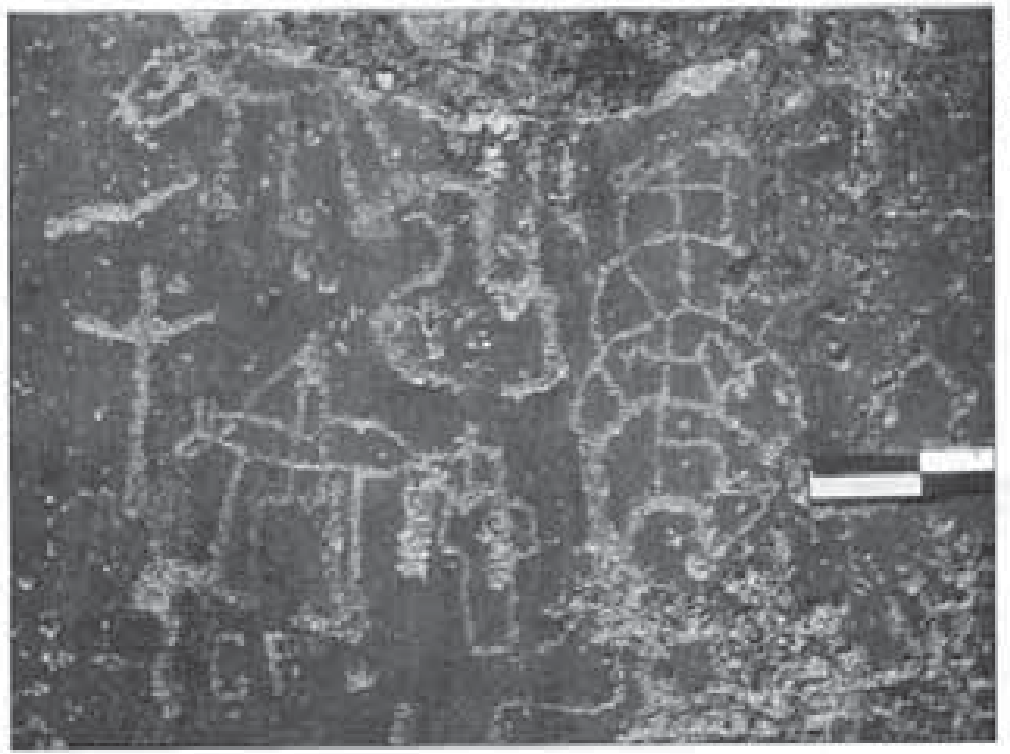

Lámina 2 Detolle de cuciformes Equidos y emparmillodos de la cucdricula $16 \mathrm{~A}$, en la pared norte del aljibe 1.

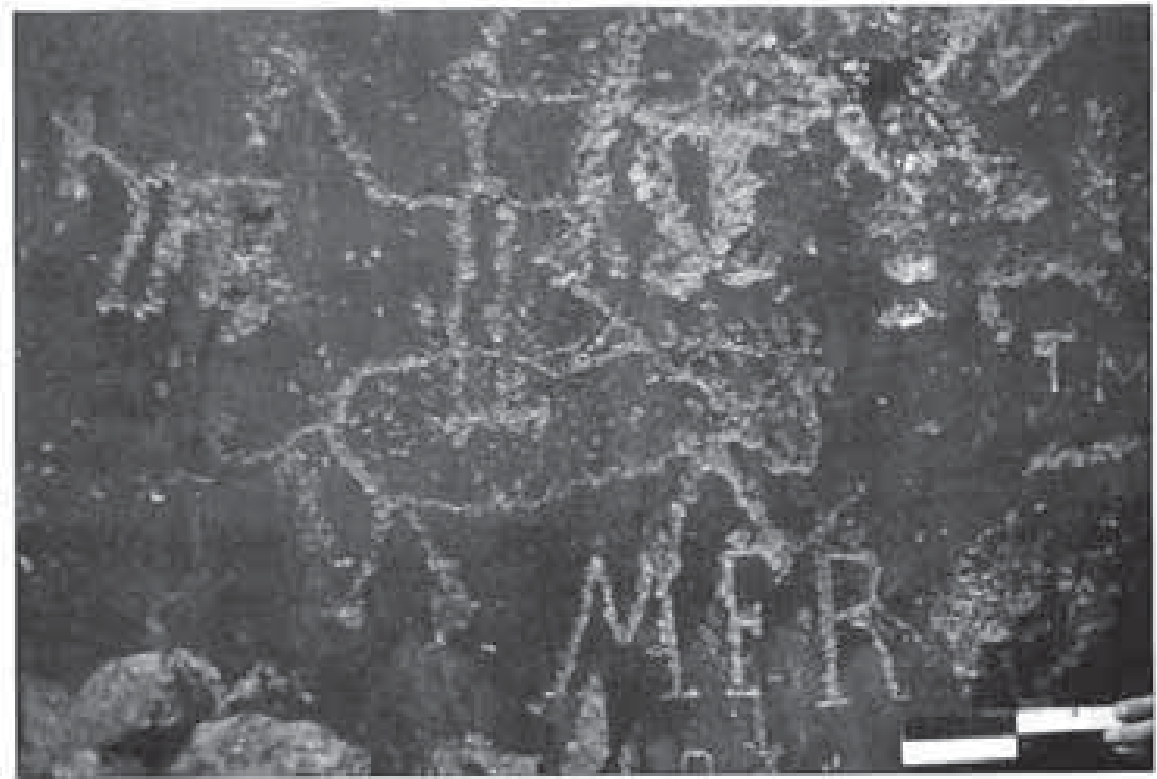

Lámina 3. Detalle de un jinete de la cuodricula 16-B, en la pared norte del aljbe 1. 


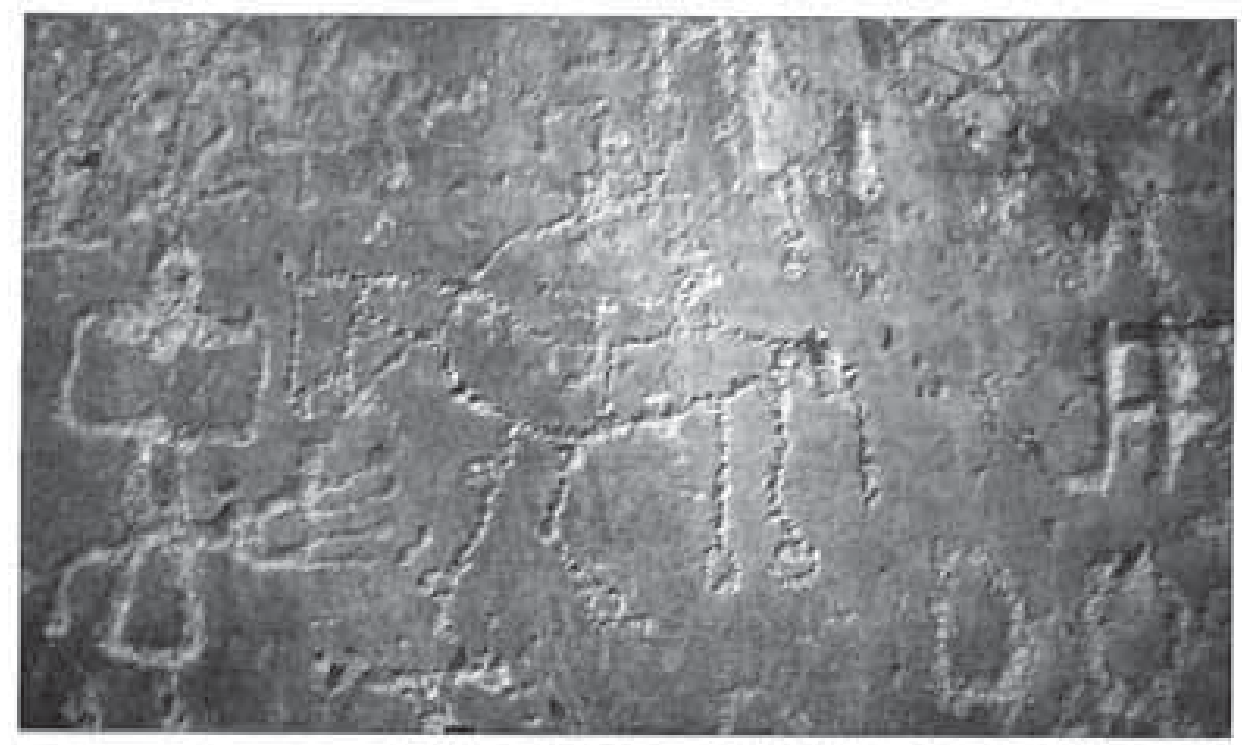

Lámina 4. Detolitc de un Équido y un antropxmarfo de la cuadícula 13-8. en la pared norte del ajibe $L$

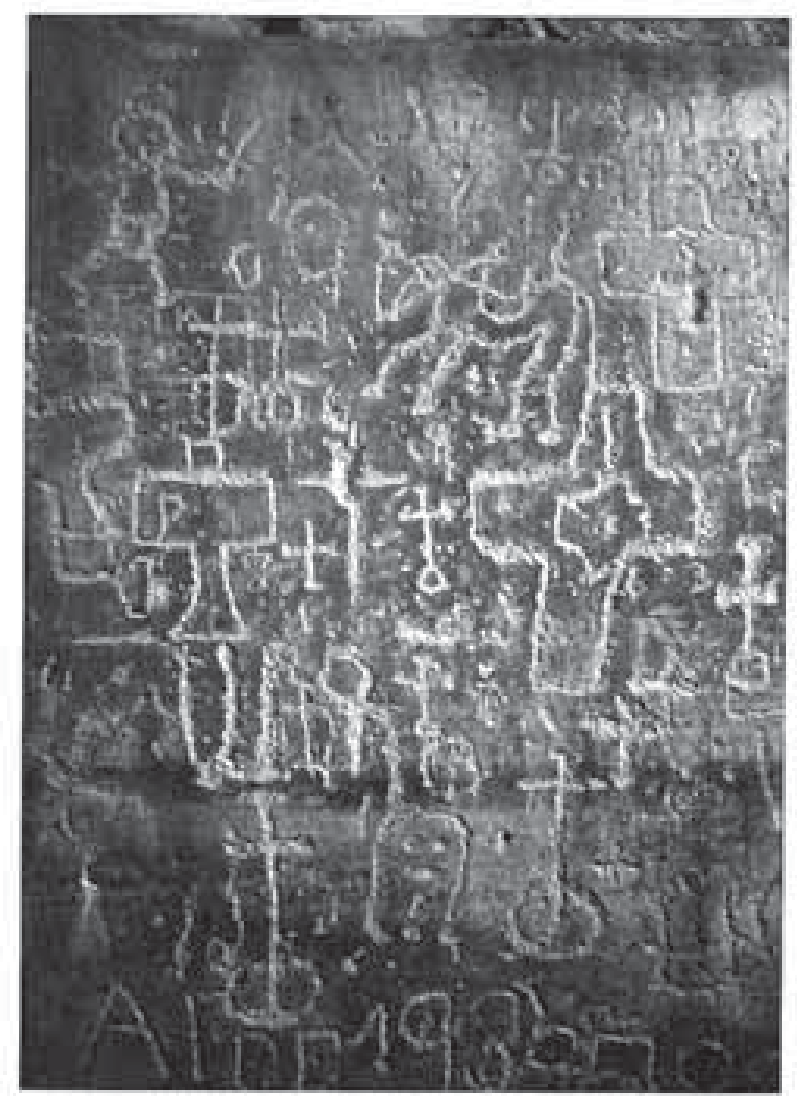

Lámina S. Conjunto de cruces équido y antropomorfo de las cuadrionios $7, A / B$, en la pored sur del ajibe i 


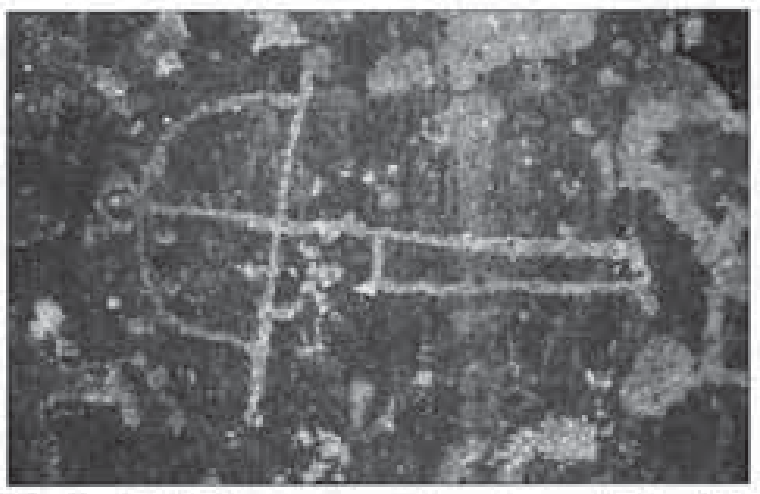

Lámina 6. Baliesta representada en la cuadricula 15-A en la pared norte del alibe L.

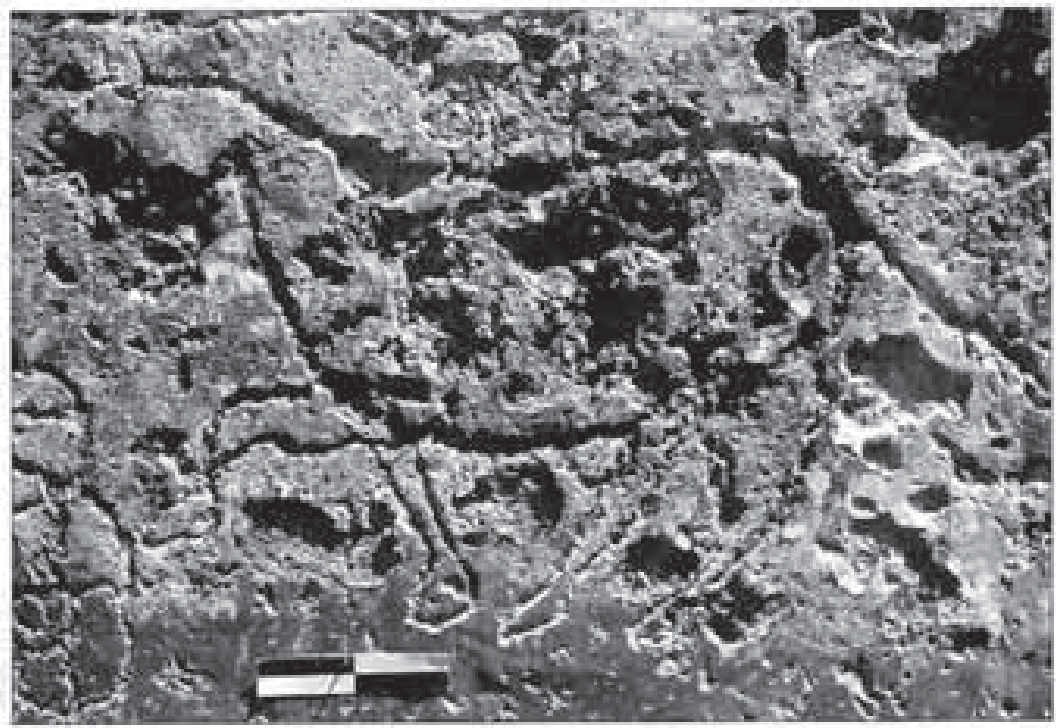

Lámina 7. Representoción de un Équido en la pared norte del aljbe II.

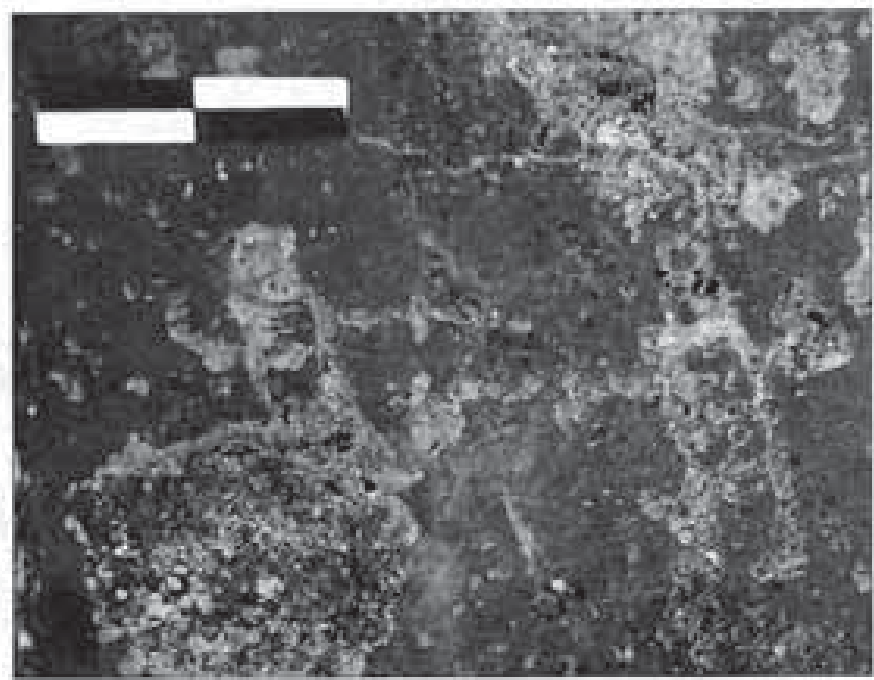

Lámina 8 . Fscena de duelo representoda en la pared este del ajibe fll. 